\title{
Article
}

\section{The Density of Group I mGlu 5 Receptors Is Reduced along the Neuronal Surface of Hippocampal Cells in a Mouse Model of Alzheimer's Disease}

\author{
Alejandro Martín-Belmonte ${ }^{1} \mathbb{D}$, Carolina Aguado ${ }^{1}$, Rocío Alfaro-Ruiz ${ }^{1}$, José Luis Albasanz ${ }^{2}$ (D), Mairena Martín ${ }^{2}$, \\ Ana Esther Moreno-Martínez ${ }^{1}$, Yugo Fukazawa ${ }^{3}$ id and Rafael Luján ${ }^{1, *(\mathbb{D})}$
}

1 Synaptic Structure Laboratory, Instituto de Investigación en Discapacidades Neurológicas (IDINE), Departamento de Ciencias Médicas, Facultad de Medicina, Campus Biosanitario, Universidad de Castilla-La Mancha, C/Almansa 14, 02006 Albacete, Spain; Alejandro.Martin@uclm.es (A.M.-B.);

Carolina.Aguado@uclm.es (C.A.); Rocio.Alfaro@uclm.es (R.A.-R.); AnaEsther.Moreno@uclm.es (A.E.M.-M.)

2 Regional Center of Biomedical Research (CRIB), Department of Inorganic, Organic and Biochemistry, Faculty of Chemical and Technological Sciences, School of Medicine of Ciudad Real, Universidad de Castilla-La Mancha, 13071 Ciudad Real, Spain; Jose.Albasanz@uclm.es (J.L.A.); Mairena.Martin@uclm.es (M.M.)

3 Research Center for Child Mental Development, Life Science Innovation Center, Division of Brain Structure and Function, School of Medical Science, University of Fukui, Fukui 910-1193, Japan; yugo@u-fukui.ac.jp

* Correspondence: Rafael.Lujan@uclm.es; Tel.: +34-967-599200 (ext. 2196)

Citation: Martín-Belmonte, A.; Aguado, C.; Alfaro-Ruiz, R.; Albasanz, J.L.; Martín, M.; Moreno-Martínez, A.E.; Fukazawa, Y.; Luján, R. The Density of Group I $\mathrm{mGlu}_{5}$ Receptors Is Reduced along the Neuronal Surface of Hippocampal Cells in a Mouse Model of Alzheimer's Disease. Int. J. Mol. Sci. 2021, 22, 5867. https://doi.org/10.3390/ijms22115867

Academic Editors: Xavier Altafaj and Francisco Ciruela

Received: 3 May 2021

Accepted: 26 May 2021

Published: 30 May 2021

Publisher's Note: MDPI stays neutral with regard to jurisdictional claims in published maps and institutional affiliations.

Copyright: (c) 2021 by the authors. Licensee MDPI, Basel, Switzerland. This article is an open access article distributed under the terms and conditions of the Creative Commons Attribution (CC BY) license (https:// creativecommons.org/licenses/by/ $4.0 /)$

\begin{abstract}
Metabotropic glutamate receptor subtype $5\left(\mathrm{mGlu}_{5}\right)$ is implicated in the pathophysiology of Alzheimer's disease (AD). However, its alteration at the subcellular level in neurons is still unexplored. Here, we provide a quantitative description on the expression and localisation patterns of mGlu $_{5}$ in the APP/PS1 model of AD at 12 months of age, combining immunoblots, histoblots and high-resolution immunoelectron microscopic approaches. Immunoblots revealed that the total amount of $\mathrm{mGlu}_{5}$ protein in the hippocampus, in addition to downstream molecules, i.e., $\mathrm{G}_{\mathrm{q} / 11}$ and PLC $\beta_{1}$, was similar in both APP/PS1 mice and age-matched wild type mice. Histoblots revealed that $\mathrm{mGlu}_{5}$ expression in the brain and its laminar expression in the hippocampus was also unaltered. However, the ultrastructural techniques of SDS-FRL and pre-embedding immunogold demonstrated that the subcellular localisation of mGlu $_{5}$ was significantly reduced along the neuronal surface of hippocampal principal cells, including CA1 pyramidal cells and DG granule cells, in APP/PS1 mice at 12 months of age. The decrease in the surface localisation of mGlu 5 was accompanied by an increase in its frequency at intracellular sites in the two neuronal populations. Together, these data demonstrate, for the first time, a loss of mGlu $_{5}$ at the plasma membrane and accumulation at intracellular sites in different principal cells of the hippocampus in APP/PS1 mice, suggesting an alteration of the excitability and synaptic transmission that could contribute to the cognitive dysfunctions in this $\mathrm{AD}$ animal model. Further studies are required to elucidate the specificity of $\mathrm{mGlu}_{5}$-associated molecules and downstream signalling pathways in the progression of the pathology.
\end{abstract}

Keywords: Alzheimer's disease; hippocampus; mGlu receptors; immunohistochemistry; electron microscopy; freeze-fracture; AD mouse model

\section{Introduction}

Alzheimer's disease (AD), the most common aetiology of dementia, is a progressive neurodegenerative condition characterised by a gradual decline in multiple cognitive functions and non-cognitive neuropsychiatric symptoms [1,2]. The three major neuropathology hallmarks of $\mathrm{AD}$ are the extracellular deposits of amyloid $\beta(\mathrm{A} \beta)$ peptides forming senile plaques, the intracellular accumulation of neurofibrillary tangles, which contain hyperphosphorylated Tau protein, and synapse loss $[3,4]$. These pathological alterations cause neuronal cell death in the hippocampus and cortical areas affecting memory formation, reasoning, language, and social behaviour [2]. Evidence suggests that $A \beta$ and Tau oligomers 
contribute to dendritic spine and synaptic loss in AD, especially in the hippocampus [5], with subsequent disturbance of the glutamatergic neurotransmission machinery [6-9].

Glutamate is the main excitatory neurotransmitter in the hippocampus $[10,11]$. The effects of glutamate are mediated by activation of ionotropic and metabotropic receptors; both involved in the fine-tuning of neuronal responses and in neuronal plasticity, which underlies learning and memory formation [12,13]. Metabotropic glutamate (mGlu) receptors are coupled via G-proteins and second messengers to various effector mechanisms to mediate the slow component of excitatory responses [14]. To date, eight different subtypes of $\mathrm{mGlu}$ receptors have been identified $\left(\mathrm{mGlu}_{1-8}\right)$, which have been classified into three groups (Group I, Group II and Group III) based on their sequence homology, transduction mechanism and pharmacology. Group I includes $\mathrm{mGlu}_{1}$ and $\mathrm{mGlu}_{5}$, which couple to the heterotrimeric $\mathrm{G}$ protein $\mathrm{G} \alpha_{\mathrm{q} / 11}$ and activate phospholipase $\mathrm{C}$, resulting in increased inositol-1,4,5-trisphosphate formation and the release of $\mathrm{Ca}^{2+}$ from intracellular stores [15]. Activation of Group I mGlu receptors in the hippocampus leads to pyramidal cell excitability and transmission through the regulation of neurotransmitter receptors and ion channels $[14,16]$. Group I mGlu receptors are also important in the induction of long-term potentiation and long-term depression $[17,18]$.

In situ hybridization and light microscopic immunohistochemical studies have shown that $\mathrm{mGlu}_{5}$ is widely expressed in the brain, being predominant in the hippocampus [19-22], where they play modulatory roles in regulating excitatory transmission at glutamatergic synapses and NMDA receptor-dependent synaptic plasticity [23]. An alteration in the signalling of $\mathrm{mGlu}_{5}$ is associated with neurological conditions and neurodegenerative diseases including $\mathrm{AD}[15,24]$. It has been demonstrated that $\mathrm{A} \beta$ oligomer induces mGlu clustering, which leads to an elevation in intracellular calcium and excitatory synapse deterioration in AD model mice $[25,26]$. In addition, mGlu $\mathrm{u}_{5}$ blockade reversed the learning and memory deficits observed in the AD mice [26]. However, it remains unclear how the distribution of $\mathrm{mGlu}_{5}$ is altered at the surface of hippocampal neurons in the AD mice.

To further understand the involvement of $\mathrm{mGlu}_{5}$ in the hippocampus of $\mathrm{AD}$, we evaluated changes in their expression and distribution in the APP/PS1 model of AD using immunoblots, histoblots and high-resolution immunohistochemical techniques in combination with quantitative approaches. We provided evidence for a significant reduction in the surface expression of $\mathrm{mGlu}_{5}$ in CA1 pyramidal cells and DG granule cells.

\section{Results}

\section{1. $m$ Glu $_{5}$ and Downstream Molecules in APP/PS1 Mice}

Given that the transduction pathway mediating the response of $\mathrm{mGlu}_{5}$ involves the activation of PLC through the $G$ protein $\mathrm{G}_{\mathrm{q} / 11}$, we first analysed, using immunoblots, the protein expression of $\mathrm{mGlu}_{5}, \mathrm{PLC} \beta_{1}$ and $\mathrm{G}_{\mathrm{q} / 11}$ in hippocampal membranes from APP/PS1 and wild type mice (Figure 1A,B). As shown in Figure 1A, no significant differences were detected in $\mathrm{mGlu}_{5}, P L C \beta_{1}$ and $\mathrm{G}_{\mathrm{q} / 11}$ expression levels in APP/PS1 mice at 12 months of age compared to age-matched wild type mice (Figure 1A,B). 


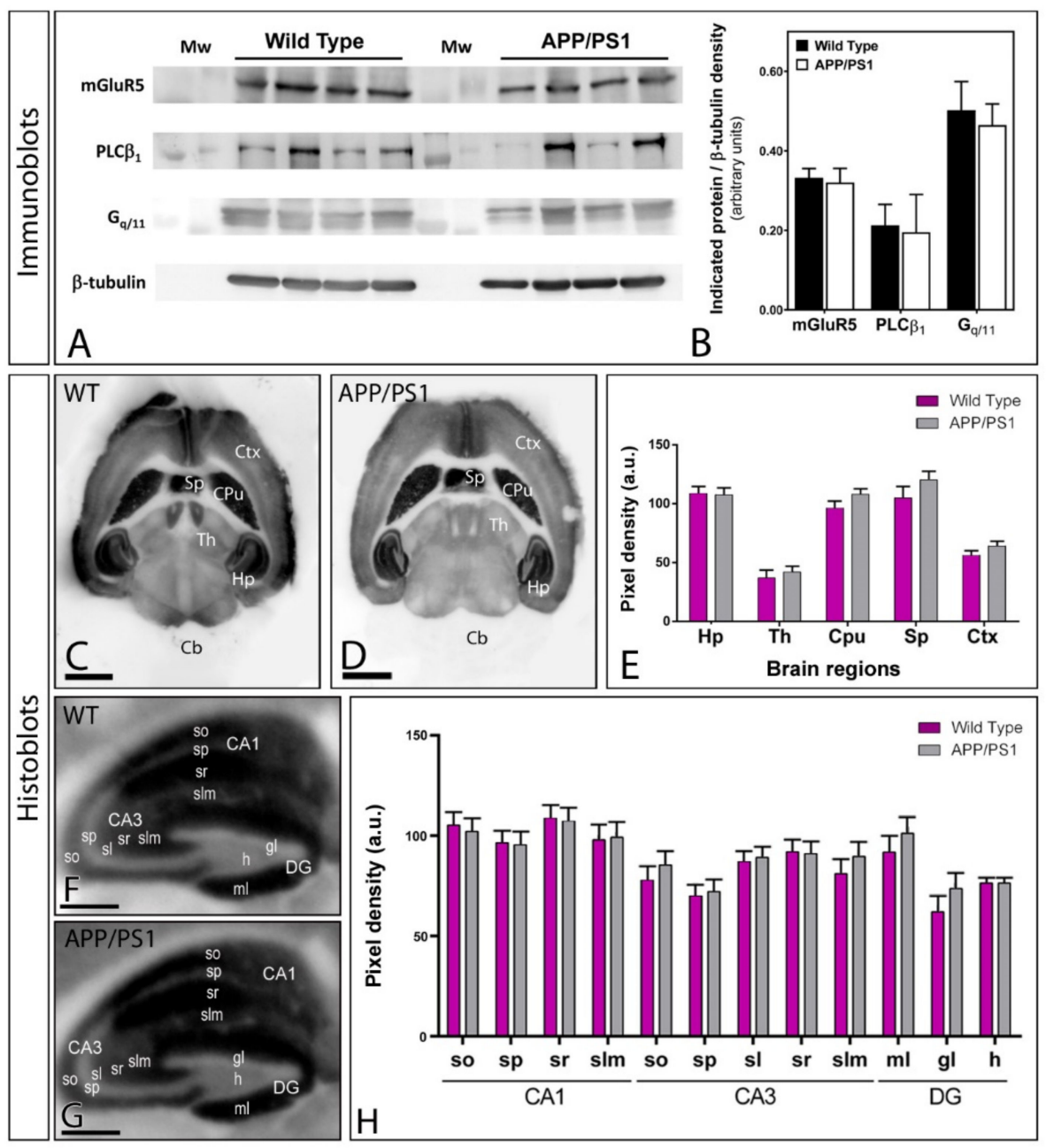

Figure 1. Expression of $\mathrm{mGlu}_{5}$ in wild type and APP/PS1 mice. (A,B) Immunoblots showing the expression of $\mathrm{mGlu}_{5}, \mathrm{PLC} \beta_{1}$ and $\mathrm{G}_{\mathrm{q} / 11}$ in hippocampal membranes from APP/PS1 and wild type mice at 12 months of age. The developed immunoblots were scanned and densitometric measurements from three independent experiments were averaged together. Quantification of the three proteins were normalised to $\beta$-tubulin and expressed as pixel density, showing no differences in APP/PS1

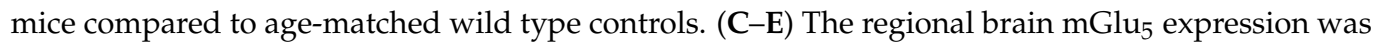
visualised in histoblots of horizontal brain sections at 12 months of age in wild type and APP/PS1 mice using an affinity-purified anti-mGlu ${ }_{5}$ antibody. The expression of $\mathrm{mGlu}_{5}$ in different brain regions was determined by densitometric analysis of the scanned histoblots. The expression of $\mathrm{mGlu}_{5}$ revealed marked region-specific differences, with the strongest immunoreactivity in the hippocampus $(\mathrm{Hp})$, caudate putamen $(\mathrm{CPu})$ and septum $(\mathrm{Sp})$, and moderate labelling in the cortex (Ctx) and thalamus (Th). The weakest expression level was detected in the cerebellum $(\mathrm{Cb})$. Densitometric analysis showed no differences in mGlu $_{5}$ expression in APP/PS1 mice compared to age-matched wild type controls at the ages employed. $(\mathrm{F}, \mathrm{G})$ Hippocampal expression and distribution of $\mathrm{mGlu}_{5}$ in wild type and APP/PS1 mice visualised in histoblots of horizontal sections at 12 months of age. (H) Expression for $\mathrm{mGlu}_{5}$ was strong in all dendritic layers of the CA1 and CA3 region and DG, with the strata oriens (so) and radiatum (sr) of the CA1 region showing the highest expression levels. A more moderate expression was observed in the stratum lacunosum-moleculare (slm) of CA1, and the strata oriens (so), radiatum (sr) and lacunosum-moleculare (slm) of CA3, with the molecular layer (ml) and hilus (h) of the DG showing the lowest expression level. Densitometric analysis showed no differences in $\mathrm{mGlu}_{5}$ expression in APP/PS1 mice compared to age-matched wild type controls. Error bars indicate SEM. Scale bars: (C,D), $0.2 \mathrm{~cm} ;(\mathbf{F}, \mathrm{G}), 0.05 \mathrm{~cm}$. 


\subsection{Similar Regional and Cellular Expression of $m \mathrm{Glu}_{5}$ in Control and APP/PS1 Mice}

As immunoblots are not informative regarding potential regional- or cell-type-specific changes, we next analysed the region-dependent expression of $\mathrm{mGlu}_{5}$ in the brain of APP/PS1 and wild type mice using an mGlu ${ }_{5}$ subtype-specific antibody in conventional histoblots [27] at 12 months of age (Figure 1C-E). The brain expression of mGlu 5 protein revealed marked region-specific differences, with the strongest immunolabelling in the hippocampus, caudate putamen and septum, moderate labelling in the cortex and thalamus, and very weak labelling in the cerebellum (Figure 1C,D). Quantification of mGlu expression levels revealed no differences between wild type and APP/PS1 mice (Figure 1E). Similar regional expression patterns and an absence of differences were also observed at 1 and 6 months of age (Figure S1).

We next analysed the laminar expression and distribution pattern of $\mathrm{mGlu}_{5}$ in the hippocampus using histoblots at 12 months of age (Figure 1F-H). Immunostaining for mGlu $_{5}$ was widely expressed in all hippocampal subfields and dendritic layers of wild type and APP/PS1 mice, showing similar expression patterns in both genotypes (Figure 1F-H).

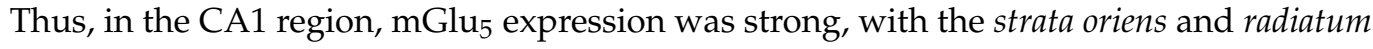
showing the highest and the stratum lacunosum-moleculare showing lower expression levels

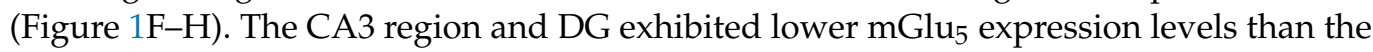
CA1 region, with the strata lucidum and lacunosum-moleculare, as well as the molecular layer and hilus of the DG, showing the lowest expression level within the hippocampus (Figure $1 \mathrm{~F}-\mathrm{H}$ ). The stratum pyramidale and granule cell layer showed the weakest expression level throughout (Figure 1F-H). Similar laminar expression patterns were observed in the hippocampus of wild type and APP/PS1 mice at 1 and 6 months (Figure S2).

At the cellular level, although immunoreactivity for mGlu $_{5}$ was present mainly in the neuropil in all dendritic layers, labelling could only be seen rarely outlining the somata and dendrites of scattered interneurons in all areas, particularly in the hilus, indicating the preferential distribution in CA1 and CA3 pyramidal cells and granule cells in the DG, with similar patterns in both APP/PS1 mice and WT (Figure S3).

\subsection{Reduction of $m \mathrm{Glu}_{5}$ in the Surface of CA1 Pyramidal Cells in APP/PS1 Mice}

Using the highly-sensitive SDS-FRL technique, we first investigated the organization of $\mathrm{mGlu}_{5}$ along the surface of CA1 pyramidal cells and their possible alteration in the hippocampus of APP/PS1 mice at 12 months of age. Electron microscopic analysis of the hippocampal replicas revealed immunogold labelling distributed only on P-faces of pyramidal cells, in agreement with the location of the sequence specifying the mGlu $\mathrm{u}_{5}$ in the intracellular carboxy terminal tail. Consistent with previous pre-embedding immunogold labelling studies [21,22], $\mathrm{mGlu}_{5}$ was detected along the postsynaptic membrane of the entire somato-dendritic compartment of CA1 principal cells (Figures 2 and 3).

In wild type mice, immunoparticles for mGlu $_{5}$ were observed throughout the dendritic spines, dendritic shafts in strata oriens, radiatum and lanunosum-moleculare of the CA1 region (Figure 2A,C-F) and somata of pyramidal cells in the stratum pyramidale (Figure 2B). The neuronal compartments that showed the highest density of immunoparticles for mGlu were dendritic spines, and then dendritic shafts and somata (Figure 2A,C-F) (Table 1). In the eight neuronal compartments analysed, immunoparticles for mGlu $\mathrm{u}_{5}$ were mostly found forming clusters (2847 immunoparticles out of 4170) along the neuronal surface

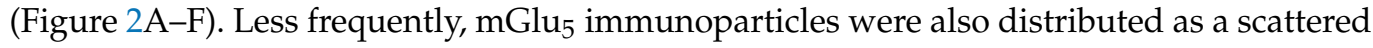
pattern (1323 immunoparticles out of 4170) (Figure 2A-F). Immunoparticles for mGlu were only confined to somato-dendritic domains of CA1 pyramidal cells and not observed at pre-synaptic sites, which is consistent with previous studies [21,22]. E-faces of pyramidal cells are free of mGlu $\mathrm{u}_{5}$ immunoparticles, as well as cross-fractures of dendrites or spines

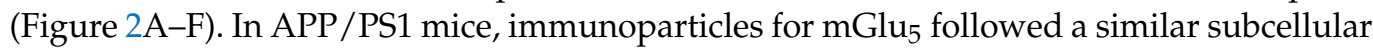
localisation pattern to that described above for wild type, although the intensity of labelling changed significantly, with fewer immunoparticles per cluster and fewer clustered (399 im- 
munoparticles out of 920) and scattered (521 immunoparticles out of 920) immunoparticles detected along the surface of CA1 pyramidal cells (Figure 2G-L).

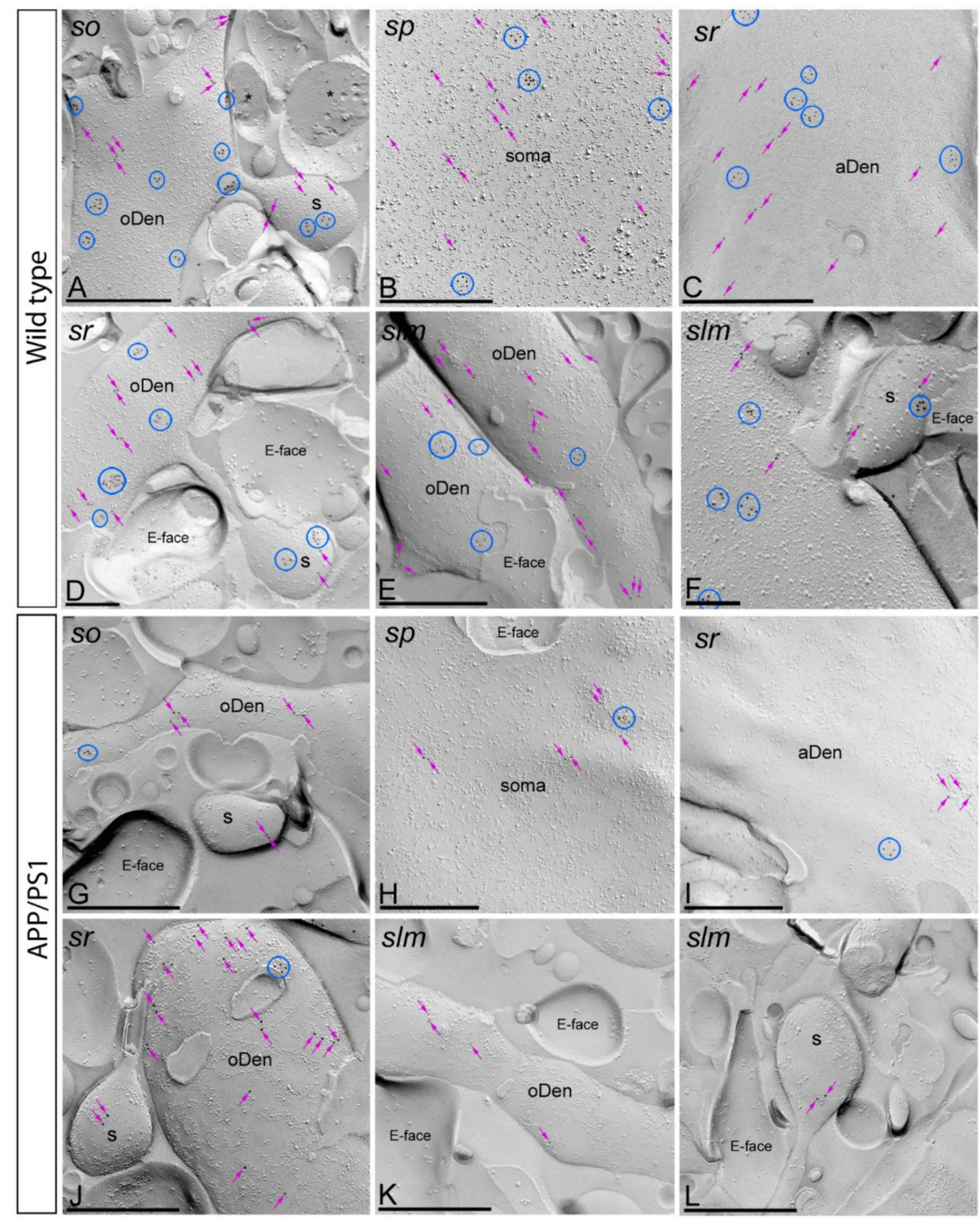

Figure 2. Subcellular localisation of $\mathrm{mGlu}_{5}$ in somato-dendritic domains of CA1 pyramidal cells in wild type and APP/PS1 mice. (A-F) Electron micrographs obtained from different subfields of the CA1 region showing immunoparticles for $\mathrm{mGlu}_{5}$ along the surface of pyramidal cells, as detected using the SDS-FRL technique in wild type mice at 12 months of age. Immunoparticles for mGlu $_{5}$ were detected forming clusters (blue circles) or scattered (purple arrows) associated with the P-face in the soma, apical dendrites (aDen), oblique dendrites (oDen) and dendritic spines (s) of CA1 pyramidal cells. Cross-fractures are indicated with asterisks $\left(^{*}\right)$. The E-face is free of mGlu immunolabelling. (G-L) Electron micrographs obtained from different subfields of the CA1 region showing immunoparticles for mGlu m $_{5}$ along the surface of pyramidal cells, as detected using the SDS-FRL technique in APP/PS1 mice at 12 months of age. Immunoparticles for mGlu 5 were detected, at low frequency, forming clusters (blue circles) or scattered (purple arrows) associated with the P-face in the soma, apical dendrites (aDen), oblique dendrites (oDen) and dendritic spines (s) of CA1 pyramidal cells. Cross-fractures are indicated with asterisks $\left(^{*}\right)$. The E-face is free of $\mathrm{mGlu}_{5}$ immunolabelling. Abbreviations: so, stratum oriens; sp, stratum pyramidale; sr, stratum radiatum; slm, stratum lacunosum-moleculare. Scale bars: (A-C,E,G-L) $0.5 \mu \mathrm{m} ;(\mathbf{D}, \mathbf{F}), 0.2 \mu \mathrm{m}$. 
Table 1. Distribution of $\mathrm{mGlu}_{5}$ immunoparticles along the membrane surface of CA1 pyramidal cells and DG granule cells at 12 months of age.

\begin{tabular}{|c|c|c|c|}
\hline & & Wild Type & APP/PS1 \\
\hline & & $\begin{array}{c}\text { Mean } \pm \text { SEM } \\
\left(\text { Immunoparticles } / \mu \mathrm{m}^{2}\right)\end{array}$ & $\begin{array}{c}\text { Mean } \pm \text { SEM } \\
\left(\text { Immunoparticles } / \mu \mathrm{m}^{2}\right)\end{array}$ \\
\hline \multirow{12}{*}{ せ } & Stratum oriens & & \\
\hline & Oblique Dendrites & $56.02 \pm 3.16$ & $20.83 \pm 2.01$ \\
\hline & Spines & $79.54 \pm 7.37$ & $34.05 \pm 4.93$ \\
\hline & Stratum pyramidale & & \\
\hline & Soma & $26.23 \pm 1.75$ & $3.57 \pm 0.92$ \\
\hline & Stratum radiatum & & \\
\hline & Apical Dendrites & $30.58 \pm 5.54$ & $2.43 \pm 0.47$ \\
\hline & Oblique Dendrites & $64.26 \pm 3.91$ & $20.79 \pm 1.68$ \\
\hline & Spines & $112.18 \pm 10.26$ & $43.23 \pm 5.00$ \\
\hline & $\begin{array}{c}\text { Stratum } \\
\text { lacunosum-moleculare }\end{array}$ & & \\
\hline & Oblique Dendrites & $30.32 \pm 2.00$ & $11.25 \pm 1.24$ \\
\hline & Spines & $50.90 \pm 4.51$ & $17.27 \pm 3.15$ \\
\hline \multirow{5}{*}{ ڤִ } & Granule cell layer & & \\
\hline & Soma & $24.01 \pm 1.84$ & $2.70 \pm 0.98$ \\
\hline & Molecular layer & & \\
\hline & Oblique Dendrites & $29.79 \pm 3.75$ & $8.25 \pm 1.59$ \\
\hline & Spines & $73.86 \pm 14.00$ & $17.07 \pm 2.43$ \\
\hline
\end{tabular}

Next, we performed a quantitative comparison of the $\mathrm{mGlu}_{5}$ densities in eight different somato-dendritic compartments in the CA1 region (Figure 3A) (Table 1). In wild type mice, our data revealed a graded increase in the density of $\mathrm{mGlu}_{5}$ immunoparticles from the soma to the dendritic spines in strata radiatum (Figure 3A). Although a somato-dendritic gradient was also observed in APP/PS1 mice, we found a significant decrease in mGlu $_{5}$ densities in all layers analysed (Two-way ANOVA test and Bonferroni post hoc test, $* * * * p<0.0001$ ) (Figure 3A) (Table 1). To determine how this reduction in density is taking place, we analysed the composition of clusters of $\mathrm{mGlu}_{5}$ immunoparticles along the neuronal surface in the eight compartments (Figure 3B), and kept the surface area and number of profiles similar to avoid neuronal alterations induced by AD (Table 2). Combining all oblique dendrites from strata oriens, radiatum and lacunosum-moleculare, we detected a total of 72 clusters with a range of 3 to 9 immunoparticles in APP/PS1 mice, while, for those with similar surface area, we detected 452 clusters with a range of 3 to 20 immunoparticles for $\mathrm{mGlu}_{5}$ in wild type mice (Figure 3B). Combining all spines from the three dendritic layers, we detected a total of 13 clusters with a range of 3 to 4 immunoparticles in APP/PS1 mice, while we detected 79 clusters with a range of 3 to 13 immunoparticles for mGlu in wild type mice (Figure 3B). The analysis performed individually in each of the eight compartments showed that the number and size of clusters of mGlu immunoparticles were reduced in the APP/PS1 mice compared to age-matched wild type (Table 2). 


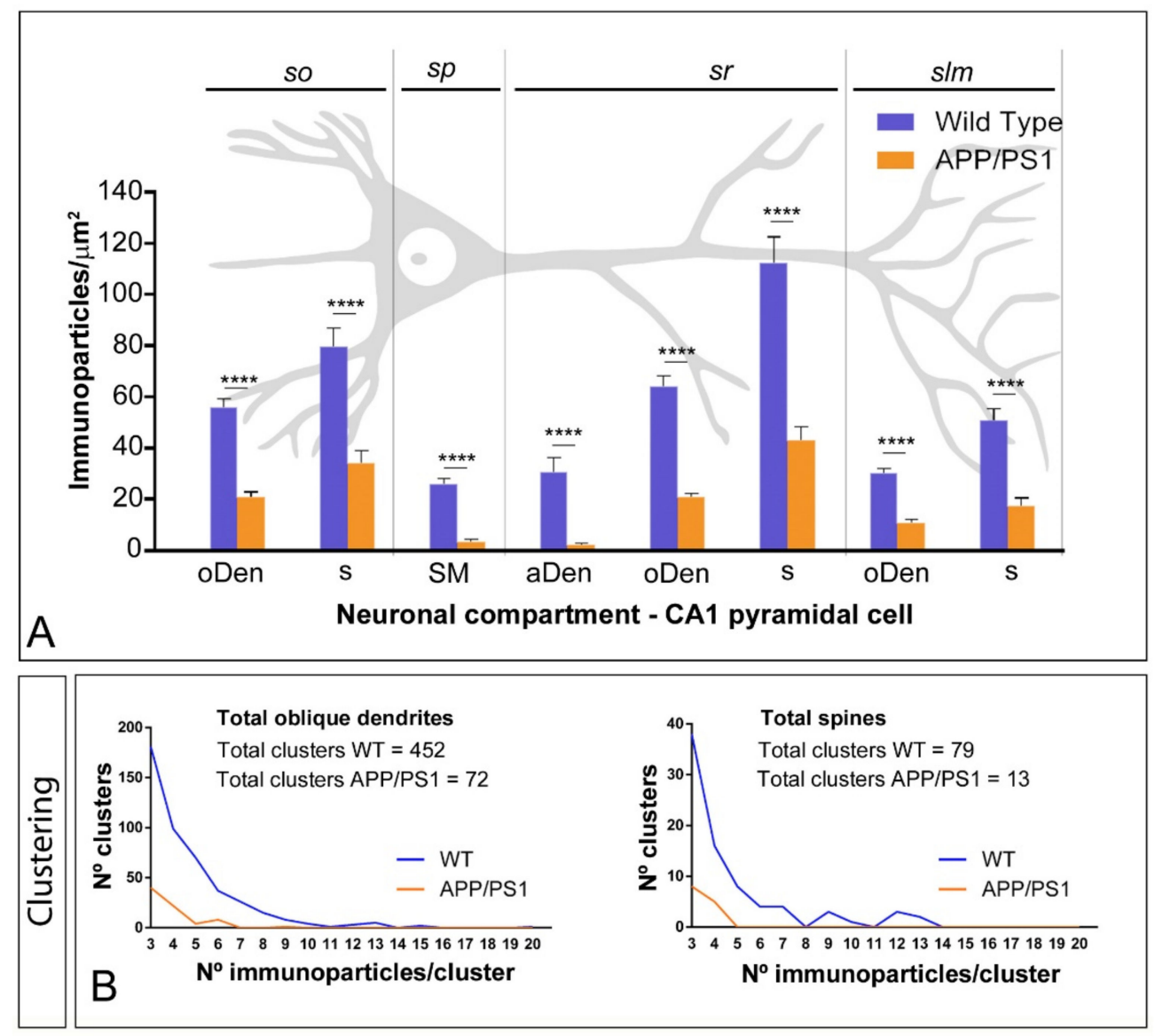

Figure 3. Quantitative analysis of $\mathrm{mGlu}_{5}$ immunoparticles along the surface of CA1 pyramidal

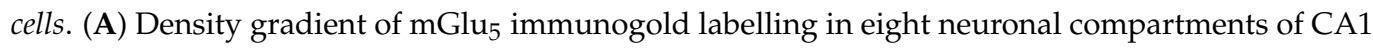
pyramidal cells in wild type and APP/PS1 mice at 12 months. The density gradient of surface

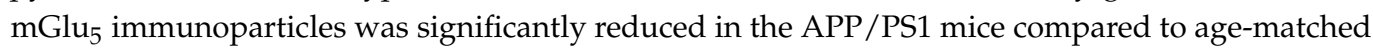
wild type controls in all strata and subcellular compartments analysed (Two-way ANOVA test and Bonferroni post hoc test, ${ }^{* * * *} p<0.0001$ ) (Table 1). Error bars indicate SEM. Abbreviations: so, stratum oriens; sp, stratum pyramidale; sr, stratum radiatum; slm, stratum lacunosum-moleculare; aDen, apical dendrite; oDen, oblique dendrite; s, spine; SM, soma. (B) Histograms showing composition of clusters in all oblique dendrites and all spines of CA1 pyramidal cells. For all of the oblique

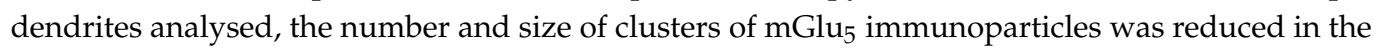
APP /PS1 mice (72 clusters with a range of 3 to 9 immunoparticles in oblique dendrites; 13 clusters with a range of 3 to 4 immunoparticles in spines) compared to age-matched wild type controls (452 clusters with a range of 3 to 20 immunoparticles in oblique dendrites; 79 clusters with a range of 3 to 13 immunoparticles in spines).

\subsection{Reduction of $m \mathrm{Glu}_{5}$ in the Surface of DG Granule Cells in APP/PS1 Mice}

Using the same methodological approaches, we also investigated the organisation of mGlu $_{5}$ along the surface of granule cells in the DG (Figure 4). In wild type mice, mGlu $_{5}$ immunoparticles were distributed in dendritic spines and shafts through the molecular layer of the DG, as well as in somata of granule cells in the granule cell layer, mainly forming clusters (689 immunoparticles out of 1192) but also scattered (503 immunoparticles out of

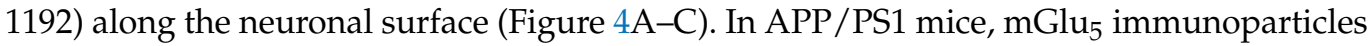
were observed in the same subcellular compartments, but immunolabelling intensity was reduced and the clustered distribution pattern (35 immunoparticles out of 211) observed in wild type changed to a predominantly scattered pattern (176 immunoparticles out of 211) (Figure 4D-F). This change in subcellular localisation pattern was confirmed performing quantitative analyses in three different somato-dendritic compartments in granule cells 


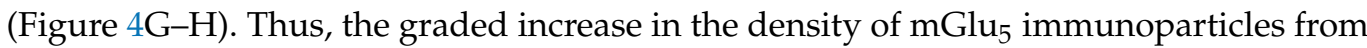
the soma to the dendritic spines observed in wild type mice was significantly reduced in all neuronal compartments of granule cells in APP/PS1 mice (Two-way ANOVA test and Bonferroni post hoc test, ${ }^{* * *} p<0.001,{ }^{* * * *} p<0.0001$ ) (Figure 4G) (Table 1). This reduction in density was due to a reduction in the number and composition of mGlu immunoparticles $^{2}$ forming clusters along the neuronal surface of granule cells (Figure $4 \mathrm{H}$ ). Thus, in dendritic spines, we did not detect any cluster with three or more immunoparticles in APP/PS1 mice, while among those with similar surface area, we detected 26 clusters with a range of 3 to 16 immunoparticles for $\mathrm{mGlu}_{5}$ in wild type mice (Figure $4 \mathrm{H}$ ). In oblique dendrites, we detected a total of eight clusters with a range of 3 to 5 immunoparticles in APP/PS1 mice, while we detected 75 clusters with a range of 3 to 20 immunoparticles for mGlu in wild type mice (Figure $4 \mathrm{H})$.

Table 2. Composition of clusters of $\mathrm{mGlu}_{5}$ immunoparticles along the membrane surface of CA1 pyramidal cells and DG granule cells at 12 months of age.

\begin{tabular}{|c|c|c|c|c|c|c|c|}
\hline \multicolumn{4}{|c|}{ Wild Type } & \multicolumn{4}{|c|}{ APP/PS1 } \\
\hline $\begin{array}{c}\text { No. } \\
\text { Profiles }\end{array}$ & $\begin{array}{c}\text { Area } \\
\text { Profiles }\end{array}$ & $\begin{array}{c}\text { No. } \\
\text { Clusters }\end{array}$ & $\begin{array}{c}\text { Range } \\
\text { Gold Particles }\end{array}$ & $\begin{array}{c}\text { No. } \\
\text { Profiles }\end{array}$ & $\begin{array}{c}\text { Area } \\
\text { Profiles }\end{array}$ & $\begin{array}{c}\text { No. } \\
\text { Clusters }\end{array}$ & $\begin{array}{c}\text { Range } \\
\text { Gold Particles }\end{array}$ \\
\hline 24 & $22 \mu \mathrm{m}^{2}$ & 184 & $13-3$ & 24 & $21 \mu \mathrm{m}^{2}$ & 27 & $6-3$ \\
\hline 24 & $1.8 \mu \mathrm{m}^{2}$ & 29 & $13-3$ & 24 & $1.7 \mu \mathrm{m}^{2}$ & 6 & $4-3$ \\
\hline 15 & $17 \mu \mathrm{m}^{2}$ & 74 & $11-3$ & 15 & $21 \mu \mathrm{m}^{2}$ & 8 & $10-3$ \\
\hline 15 & $17 \mu \mathrm{m}^{2}$ & 38 & $11-3$ & 15 & $21 \mu \mathrm{m}^{2}$ & 9 & $5-3$ \\
\hline 24 & $20 \mu \mathrm{m}^{2}$ & 209 & $20-3$ & 24 & $18 \mu \mathrm{m}^{2}$ & 34 & $9-3$ \\
\hline 30 & $2 \mu \mathrm{m}^{2}$ & 33 & $9-3$ & 30 & $1.9 \mu \mathrm{m}^{2}$ & 7 & $4-3$ \\
\hline 24 & $15 \mu \mathrm{m}^{2}$ & 59 & $9-3$ & 24 & $14 \mu \mathrm{m}^{2}$ & 14 & $5-3$ \\
\hline 27 & $2 \mu \mathrm{m}^{2}$ & 17 & $5-3$ & 27 & $1.9 \mu \mathrm{m}^{2}$ & 0 & \\
\hline 183 & $97 \mu \mathrm{m}^{2}$ & 643 & & 183 & $100 \mu \mathrm{m}^{2}$ & 103 & \\
\hline 10 & $14 \mu \mathrm{m}^{2}$ & 49 & $13-3$ & 10 & $13 \mu \mathrm{m}^{2}$ & 2 & $3-3$ \\
\hline 18 & $22 \mu \mathrm{m}^{2}$ & 75 & $20-3$ & 18 & $21 \mu \mathrm{m}^{2}$ & 8 & $5-3$ \\
\hline 21 & $4 \mu \mathrm{m}^{2}$ & 26 & $16-3$ & 21 & $4 \mu \mathrm{m}^{2}$ & 0 & 0 \\
\hline 49 & $40 \mu \mathrm{m}^{2}$ & 150 & & 49 & $38 \mu \mathrm{m}^{2}$ & 11 & \\
\hline
\end{tabular}

\subsection{Increase of $m \mathrm{Glu}_{5}$ in the Cytoplasm of Hippocampal Neurons in APP/PS1 Mice}

The preceding data above show that the total amount of $\mathrm{mGlu}_{5}$ protein does not change in the hippocampus of APP/PS1, but the surface distribution in principal cells is reduced. Thus, we investigated the possible internalisation and accumulation of mGlu $\mathrm{u}_{5}$ at intracellular sites of CA1 pyramidal cells and DG granule cells (Figure 5) of APP/PS1 mice at 12 months of age. For this purpose, we used the pre-embedding immunogold technique and quantitative analyses on tissue blocks taken from the middle part of the CA1 stratum radiatum and DG molecular layer. Similar subcellular localisation patterns were observed at 1 and 6 months of age (Figure S4). 


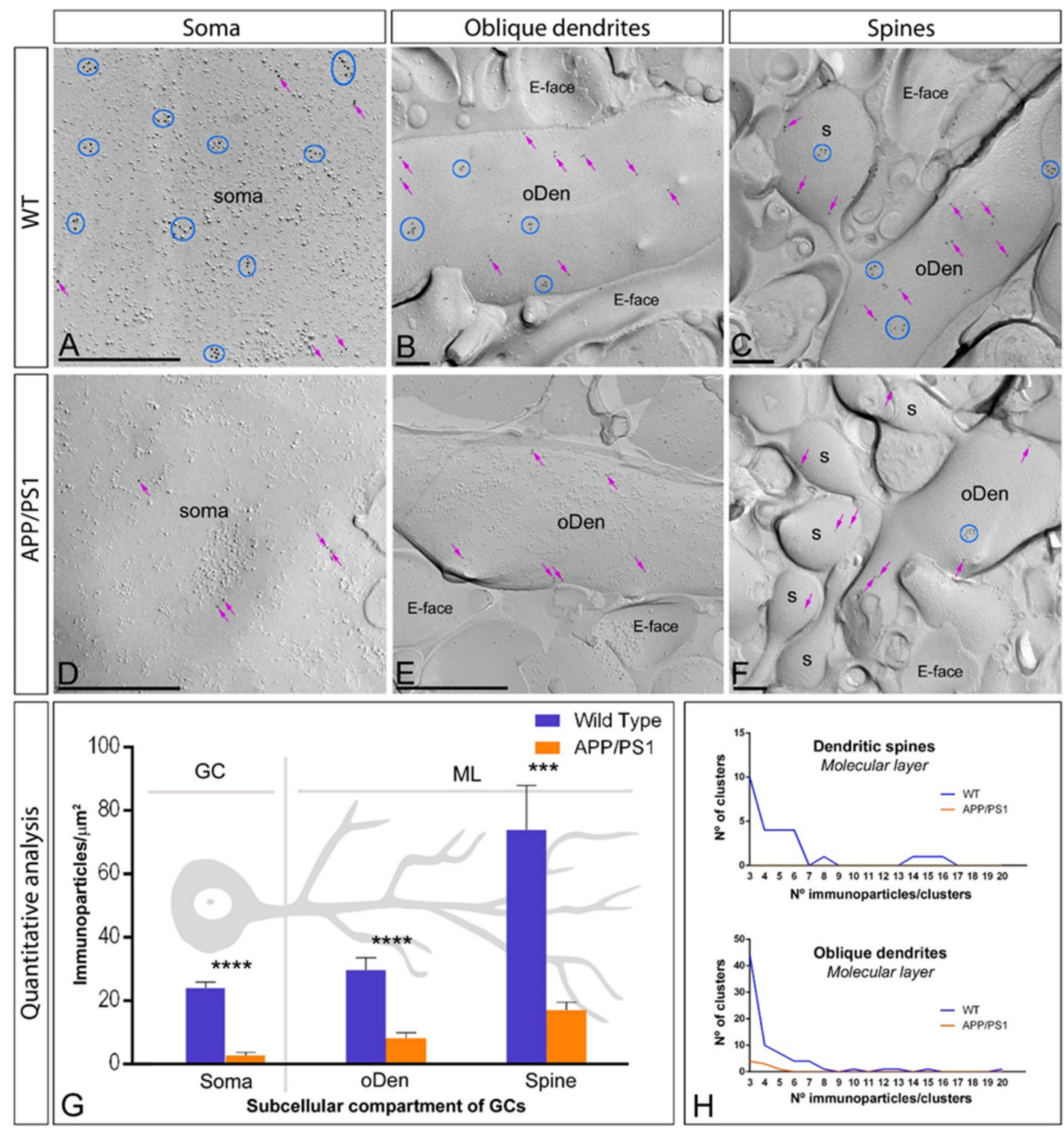

Figure 4. Subcellular localisation of $\mathrm{mGlu}_{5}$ in somato-dendritic domains of DG granule cells in wild type and APP/PS1 mice. (A-F) Electron micrographs of the DG showing immunoparticles for mGlu $\mathrm{u}_{5}$ along the surface of granule cells, as detected using the SDS-FRL technique in wild type (panels A-C) and APP/PS1 mice (panels D-F) at 12 months of age. Immunoparticles for mGlu $_{5}$ were detected forming clusters (blue circles) or scattered (purple arrows) associated with the P-face in the soma, oblique dendrites (oDen) and dendritic spines (s) of granule cells cells. (G) Quantitative analysis showing

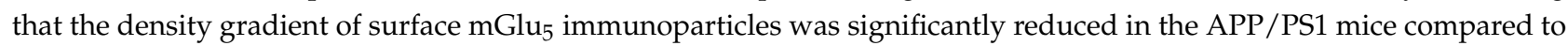
age-matched wild type controls in all strata and subcellular compartments analysed (Two-way ANOVA test and Bonferroni post hoc test, ${ }^{* * *} p<0.001,{ }^{* * *} p<0.0001$ ) (Table 1). Error bars indicate SEM. (H) Histograms showing composition of clusters in dendritic spines and oblique dendrites of granule cells. The composition of clusters was reduced in the APP/PS1 mice (1 cluster with 3 immunoparticles in spines; 8 clusters with a range of 3 to 5 immunoparticles in oblique dendrites) compared to age-matched wild type controls (26 clusters with a range of 3 to 16 immunoparticles in spines; 75 clusters with a range of 3 to 20 immunoparticles in oblique dendrites). Scale bars: (A,D), $0.5 \mu \mathrm{m} ;(\mathbf{B}, \mathbf{C}, \mathbf{E}, \mathbf{F}), 0.2 \mu \mathrm{m}$. 


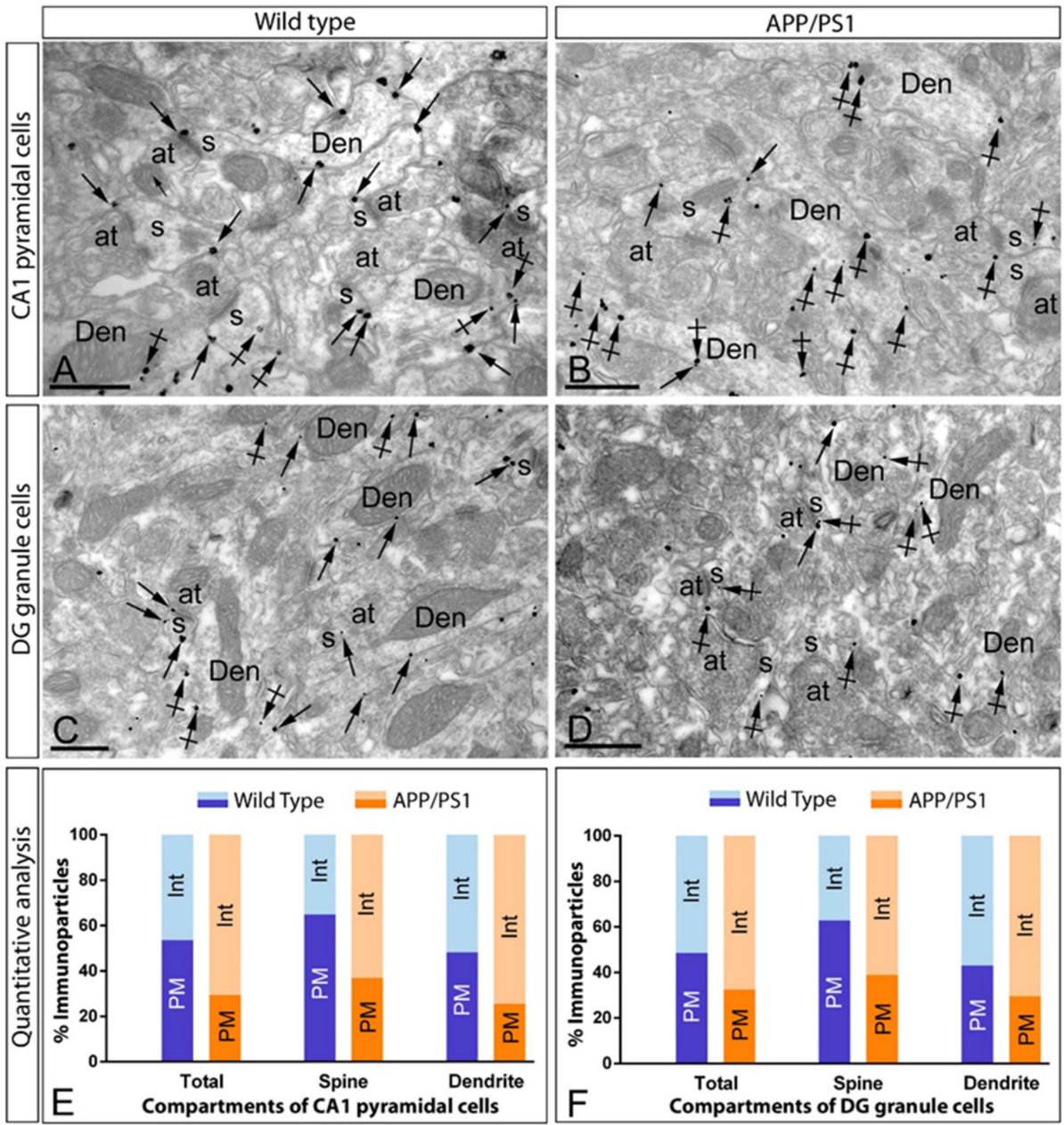

Figure 5. Intracellular distribution of $\mathrm{mGlu}_{5}$ is increased in principal cells of APP/PS1 mice. Electron micrographs showing immunoparticles for $\mathrm{mGlu}_{5}$ in the stratum radiatum of the CA1 region and molecular layer of the DG at 12 months of age in wild type and APP/PS1 mice, as detected using

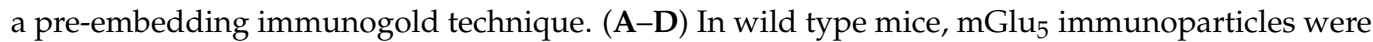
mostly located at the extrasynaptic membrane (arrows) of dendritic shafts (Den) and dendritic spines (s) of pyramidal and granule cells, and less frequently at intracellular sites (arrowheads). In

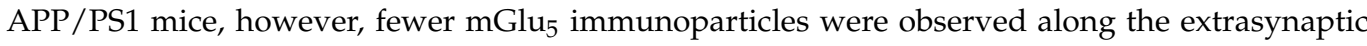
membrane (arrows) of dendritic shafts (Den) and dendritic spines (s), while more immunoparticles were observed at intracellular sites (arrowheads). (E,F) Quantitative analysis at 12 months of age demonstrating that $\mathrm{mGlu}_{5}$ immunoparticles were less frequently observed along the extrasynaptic plasma membrane of dendrites and spines of CA1 pyramidal cells and DG granule cells, and more frequently at intracellular sites in APP/PS1 mice. Scale bars: (A-D), $1 \mu \mathrm{m}$.

At the ultrastructural level, immunoparticles for $\mathrm{mGlu}_{5}$ were detected along the extrasynaptic plasma membrane of dendritic spines and shafts of CA1 pyramidal cells and DG granule cells, as well as at intracellular sites associated with intracellular membranes in the same neuronal compartments, both in wild type and APP/PS1 mice (Figure 5A-D). Quantitative analysis of pre-embedding gold particles showed clear differences in the immunolabelling present in the plasma membrane versus intracellular sites in pyramidal cells (plasma membrane: $53.65 \%$ in wild type, $n=1281$ particles, and $29.47 \%$ in APP/PS1, $n=707$ particles; intracellular: $46.35 \%$ in wild type, $n=1115$ particles, and $70.53 \%$ in APP /PS1, $n=1673$ particles) (Figure 5E) and granule cells (plasma membrane: $48.60 \%$ in wild type, $n=1012$ particles, and $32.56 \%$ in APP/PS1, $n=1081$ particles; intracellular: $51.40 \%$ in wild type, $n=1054$ particles, and $67.44 \%$ in APP $/$ PS1, $n=2250$ particles) (Figure 5F). These changes in subcellular localisation from the plasma membrane to intra- 
cellular sites were detected both in dendritic spines and dendritic shafts of CA1 pyramidal cells and DG granule cells (Figure 5E,F), thus demonstrating a redistribution of $\mathrm{mGlu}_{5}$ in hippocampal principal cells.

\section{Discussion}

G protein-coupled receptors (GPCRs) are involved in the pathogenesis of AD and in multiple stages of the processing of APP [28]. The mGlu ${ }_{5}$ subtype is a GPCRs critically involved in learning and memory $[16,29]$. Through several intracellular cascades, mGlu modulates neuronal excitability and synaptic plasticity, leading to LTP and LTD [30]. Compiling evidence highlights the potential therapeutic applicability of mGlu $u_{5}$ in AD pathophysiology $[24,31-33]$. The present study aimed at evaluating the possible changes in expression and localisation of $\mathrm{mGlu}_{5}$ in an animal model of AD at an advanced stage of the disease. In particular, we examined the subcellular localisation of mGlu in two hippocampal principal cells, the CA1 pyramidal cells and the DG granule cells in APP/PS1 mice of 12 months of age. Our findings demonstrate, for the first time, a reduction of $\mathrm{mGlu}_{5}$ in the neuronal surface of principal cells in the hippocampus of APP/PS1 mice. This decrease in mGlu $_{5}$ all over the plasma membrane in APP/PS1 mice may be a contributing factor to the memory deficits with severe synapse loss that accompany this AD model.

\subsection{Stable Expression Levels of $m G l u_{5}$ Protein in the Hippocampus of APP/PS1 Mice}

Pathological accumulation of A $\beta$ plaques throughout the hippocampus in the APP/PS1 model of AD causes critical changes in the hippocampal circuits that include degradation of dendritic spines, reductions in synapse density, decreases in synaptic AMPA receptors and increases in the intrinsic excitability of neurons [34-37]. Therefore, glutamatergic neurons are critically affected in the hippocampus of APP/PS1 mice, and compiling evidence shows that $\mathrm{mGlu}_{5}$ has a contributing role in such neurodegenerative processes. A seminal report identified a molecular interaction between $\mathrm{mGlu}_{5}$ and cellular prion protein $\left(\mathrm{PrP}^{\mathrm{C}}\right)$, both acting as a co-receptor for oligomeric $A \beta$ [26], and this macromolecular complex links mGlu 5 to intracellular signalling molecules including Homer1b/c, Pyk2, Fyn, and CaMKII $[26,38,39]$. As these molecules play major roles in synaptic plasticity, the mGlu $\mathrm{PrP}^{\mathrm{C}}$ complex mediates activation of Pyk2, Fyn and CaMKII following exposition to $\mathrm{A} \beta$, which leads to impaired LTP $[26,38,40]$.

The involvement of the glutamatergic system in $\mathrm{AD}$ is frequently paralleled with a regulation in the expression level of signalling molecules in given brain regions, as a consequence of their loss of function and neuronal cell death (reviewed by [41]). In this study, we detected no significant change in the total protein expression of $\mathrm{mGlu}_{5}$, or in its downstream molecules such as $\mathrm{G}_{\mathrm{q} / 11}$ and $\mathrm{PLC} \beta_{1}$, in hippocampal plasma membranes of 12-month-old APP/PS1 mice. This is consistent with previous studies using similar methodological approaches and the same AD model, which showed no changes in mGlu expression levels at the same age [42,43]. Similarly, although translation of findings from animals into humans is relatively unsuccessful because animal models do not faithfully reproduce $\mathrm{AD}$ pathology, studies of postmortem human brain tissue also showed no changes in the expression level of $\mathrm{mGlu}_{5}, \mathrm{G}_{\mathrm{q} / 11}$ and PLC $\beta_{1}$ in the cerebral cortex in AD, although decreased binding to $\mathrm{mGlu}$ receptors and $\mathrm{mGlu}_{1}$ expression was reported [44]. On the other hand, expression of $\mathrm{mGlu}_{5}$ appears to decline across the lifespan, as shown by in situ hybridization in rats [45]. Consistent with this data, a recent study described a downregulation of $\mathrm{mGlu}_{5}$ in the brain of Senescence-accelerated mouse prone 8 strain (SAMP8), which represents a good model for accelerated senescence and to study the initial neurodegenerative alterations in $\mathrm{AD}$ [46]. The hippocampus of 5xFAD mice, which have large deposition of $A \beta$ in the brain, has also showed reduced expression of $\mathrm{mGlu}_{5}$ compared to controls $[47,48]$. Therefore, the direct interaction between $\mathrm{A} \beta$ and $\mathrm{mGlu}_{5}$ to promote a downregulation of the receptor is dependent on the animal models of AD. 


\subsection{Postsynaptic Arrangement of $m \mathrm{Glu}_{5}$ in Principal Cells}

This study provides detailed information on the organization of mGlu $\mathrm{u}_{5}$ in the CA1 region and DG of the hippocampus in physiological and pathological conditions using immunogold particles of small size as a marker. A frequent limiting factor in immunoelectron microscopic studies is the sensitivity that often allows low immunoparticle counts [49]. In the present study, high sensitivity was achieved using the SDS-FRL technique, which offers a higher spatial resolution than standard embedding procedures, thus providing a two-dimensional distribution of receptors and ion channels and accurate data about their density along the neuronal surface $[49,50]$.

The $\mathrm{mGlu}_{5}$ is the most abundant group I receptor subtype in the CA1 region of the hippocampus, as shown by previous in situ hybridization [19] and immunohistochemical studies [20-22,51], with a low expression for the mGlu ${ }_{1}$ subtype [52,53]. However, the DG shows high levels of both $\mathrm{mGlu}_{1}$ and $\mathrm{mGlu}_{5}$ transcript and protein [21,52]. Therefore, mGlu $_{5}$ is thought to play a predominant role in regulating CA1 pyramidal cells, while $\mathrm{mGlu}_{1}$ and $\mathrm{mGlu}_{5}$ could contribute to the regulation of granule cells. Accordingly, our data show that $\mathrm{mGlu}_{5}$ was particularly strong in dendritic layers of the hippocampus in wild type and APP/PS1 mice.

At the ultrastructural level, surface-localised mGlu $_{5}$ were found mainly on the extrasynaptic plasma membrane of dendritic spines and shafts and, at lower levels, on somata of pyramidal and granule cells. This agrees with previous reports showing that the highest density of mGlu $_{5}$ was found in the perisynaptic region of dendritic spines of pyramidal cells [21], where they are generally recruited by the high levels of glutamate released during sustained synaptic transmission. Our data thus underlie the dominant postsynaptic role of mGlu $u_{5}$ as observed in previous electrophysiological studies [54]. The present quantification extends these findings and revealed that immunoparticles for mGlu 5 were present on the somato-dendritic membrane of CA1 pyramidal cells and DG granule cells. Furthermore, $\mathrm{mGlu}_{5}$ immunoparticles were distributed in a non-uniform manner, with an increasing density from the soma to dendrites and to dendritic spines. Detailed electrophysiological investigations are needed to understand how the integration of signals in principal neurons

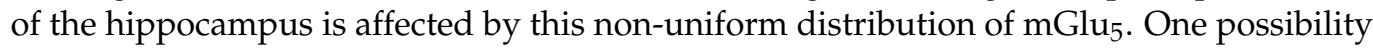
is that mGlu $_{5}$ contributes to the activity of the hippocampal microcircuit by modifying synaptic plasticity $[30,55]$.

A further interesting finding was the formation of clusters of $\mathrm{mGlu}_{5}$ immunoparticles along the neuronal surface. This preferential clustering distribution of $\mathrm{mGlu}_{5}$ on dendrites of principal cells offers an optimal position for the modulation of a variety of ion channels and neurotransmitter receptors residing in the dendritic compartments. For example, activation of $\mathrm{mGlu}_{5}$ in the hippocampus results in the modulation of small-conductance $\mathrm{Ca}^{2+}$-activated $\mathrm{K}+(\mathrm{SK})$ channels [56], transient receptor potential C (TRPC) channels [57], L-type voltage-gated $\mathrm{Ca}^{2+}$ channels [58], as well as the ionotropic AMPA and NMDA receptors [59]. Thus, glutamate activation of $\mathrm{mGlu}_{5}$ can lead to multiple signalling mechanisms and signal transduction pathways, suggesting that any possible alteration in its subcellular localisation could alter glutamate signalling in the APP/PS1 model of AD in different ways.

\subsection{Evidence for the Reduction of $m G^{\prime} u_{5}$ on the Surface of Principal Cells}

The most significant finding of the present study is the reduction in the density of $\mathrm{mGlu}_{5}$ on the plasma membrane of CA1 pyramidal cells and DG granule cells in the hippocampus of APP/PS1 mice, accompanied by an increase in the frequency of immunoparticles at intracellular sites. These changes are not the result of neuronal loss associated with disease progression, because this $\mathrm{AD}$ animal model shows significant cell death only adjacent to plaques [60], and our study was carried out in A $\beta$ plaque-free areas of the CA1 region in these animals. Recent studies reported similar plasma membrane to cytoplasm redistribution for $\mathrm{GABA}_{\mathrm{B}}$ receptors and AMPA receptors in the same neuronal compartments $[37,61,62]$. 
Although no functional studies have been performed in the present study, several implications may be inferred from our data. Decreased surface expression of mGlu $\mathbf{u}_{5}$ receptors may reduce cytoplasmic calcium $\left(\mathrm{Ca}^{2+}\right)$ concentrations. In physiological conditions, mGlu stimulates release of $\mathrm{Ca}^{2+}$ from intracellular stores and such mobilization of intracellular $\mathrm{Ca}^{2+}$ contributes to regulate glutamatergic synaptic transmission in hippocampal neurons through the activation of SK and TRPC channels [57]. Interestingly, SK channels contributes to LTP in the CA1 region, where they interact with NMDA and mGlu ${ }_{5}$ in the same dendritic spines $[56,63]$. The induction of LTP requires NMDA receptor-mediated entry of $\mathrm{Ca}^{2+}$ into dendritic spines of pyramidal cells. Activation of mGlu receptors enhances NMDA receptor currents and facilitates the induction of LTP through PKC [64]. Our findings that postsynaptic mGlu 5 are reduced in dendritic spines of CA1 pyramidal cells and DG granule cells, where they couple to NMDA receptors, suggest that $\mathrm{mGlu}_{5}$ might play a role in the alteration of LTP in these two hippocampal regions. This preferential role of $\mathrm{mGlu}_{5}$ is supported by results demonstrating that LTP can be induced in the CA1 region and the DG in mice lacking $\mathrm{mGlu}_{1}$, the other Group-I mGlu receptor [65].

In conclusion, we report here, for the first time, the ultrastructural distribution of $\mathrm{mGlu}_{5}$ along the somato-dendritic domains of pyramidal and granule cells in the hippocampus, and how this subcellular distribution is altered in APP/PS1 mice. Our findings highlight the functional importance of this redistribution as it implies a specific lack of functions for $\mathrm{mGlu}_{5}$ in the modulation of neuronal excitability in pathological conditions. This will provide a better understanding on the role of $\mathrm{mGlu}_{5}$ and associated proteins in pathological conditions and, ultimately, facilitate novel therapeutic approaches to target signalling molecules. Additional studies will further clarify the efficacy of these molecules in the progression of Alzheimer's disease.

\section{Material and Methods}

\subsection{Animals}

Male APP/PS1 mice (RRID:IMSR_MMRRC:034832) were obtained from the Jackson Laboratory (https:/ /www.jax.org/strain/005864) and expressed Mo/Hu APP695swe construct in conjunction with the exon-9-deleted variant of human presenilin 1 [Tg(APPswe, PSEN1dE9)85Dbo/Mmjax] [60,66]. The "control" wild type (WT) mice were age-matched littermates without the transgene. The following ages were selected for analysis: (i) no sign of pathology ( 1 month), (ii) first signs of $A \beta$ deposition (6 months) [60] and (iii) onset of memory deficits with severe synapse loss and widespread $A \beta$ deposition (12 months). For all ages and genotypes, mice were used as follows for the experiments: Immunoblot (4), Histoblot (4), SDS-digested freeze-fracture replica labelling (SDS-FRL) (4) and preembedding immunogold experiments (3). All mice were maintained at the Animal House Facility of the University of Castilla-La Mancha (Albacete, Spain) in cages of 2 or more mice, on a 12-h light/12-h dark cycle at $24{ }^{\circ} \mathrm{C}$ and received food and water ad libitum. Care and handling of animals prior to and during experimental procedures were in accordance with Spanish (RD 1201/2015) and European Union regulations (86/609/EC), and all protocols and methodologies were approved by the local Animal Care and Use Committee.

For immunoblotting and histoblotting, animals were deeply anesthetised by intraperitoneal injection of ketamine/xylazine 1:1 (ketamine, $100 \mathrm{mg} / \mathrm{kg}$; xylazine, $10 \mathrm{mg} / \mathrm{kg}$ ). The hippocampus was dissected, frozen rapidly in liquid nitrogen and stored at $-80^{\circ} \mathrm{C}$. For immunohistochemistry experiments at both the light microscopic and electron microscopic level, using the pre-embedding immunogold technique, animals were firstly deeply anaesthetised by intraperitoneal injection of ketamine/xylazine $1: 1$ (ketamine, $100 \mathrm{mg} / \mathrm{kg}$; xylazine, $10 \mathrm{mg} / \mathrm{kg}$ ) and then transcardially perfused with ice-cold fixative containing $4 \%(w / v)$ paraformaldehyde with $0.05 \%(v / v)$ glutaraldehyde in $0.1 \mathrm{M}$ phosphate buffer (PB, pH 7.4) for $15 \mathrm{~min}$. After perfusion, brains were removed and immersed in the same fixative for $2 \mathrm{~h}$ or overnight at $4{ }^{\circ} \mathrm{C}$. Tissue blocks were washed thoroughly in $0.1 \mathrm{M} \mathrm{PB}$. Coronal sections (60 $\mu \mathrm{m}$ thickness) were cut using a Vibratome (Leica V1000, Leica, Wetzlar, Germany). For SDS-FRL, see below. 


\subsection{Antibodies and Chemicals}

For immunoblots, we used rabbit anti-mGlu 5 polyclonal antibody (1:500, GTX133288, Genetex, Inc., Alton Pkwy Irivine, CA, USA), rabbit anti- $\mathrm{G}_{\mathrm{q} / 11}$ polyclonal antibody (1:500, 06-709, Upstate Biotechnology Inc., Lake Placid, NY, USA), mouse anti-PLC $\beta_{1}$ monoclonal antibody (1:500, 05-164, Upstate), and mouse anti- $\beta$ tubulin monoclonal antibody (1:2000, 05-661, Upstate). For SDS-FRL and pre-embedding immunogold labelling, we used rabbit anti-mGlu 5 polyclonal antibody (Rb-Af300; aa. 1144-1171 of mouse mGlu 5 ; RRID: AB_2571802; Frontier Institute Co., Sapporo, Japan) and a guinea pig anti-mGlu 5 polyclonal antibody (GP-Af270; aa. 1144-1171 of mouse mGlu; ;RID: AB_2571804; Frontier Institute Co., Sapporo, Japan). The preparation, purification and full characterization of these antibodies has been described previously $[67,68]$. The specificity of the rabbit anti-mGlu 5 polyclonal antibody (Rb-Af300) using SDS-FRL in mGluR5 KO mice has been described previously [56].

The secondary antibodies used were as follows: goat anti-mouse IgG-horseradish peroxidase (1:2000; Santa Cruz Biotechnology, Santa Cruz, CA, USA), goat anti-rabbit IgGhorseradish peroxidase (1:15,000; Thermo Fisher Scientific, Waltham, MS, USA), alkaline phosphatase (AP)-goat anti-mouse IgG $(\mathrm{H}+\mathrm{L})$ and AP-goat anti-rabbit IgG $(\mathrm{H}+\mathrm{L})(1: 5000$; Invitrogen, Paisley, UK), anti-rabbit IgG conjugated to $10 \mathrm{~nm}$ gold particles and antiguinea IgG conjugated to $10 \mathrm{~nm}$ gold particles (1:100; British Biocell International, Cardiff, $\mathrm{UK})$, anti-rabbit IgG coupled to $1.4 \mathrm{~nm}$ gold or anti-guinea IgG coupled to $1.4 \mathrm{~nm}$ gold (Nanoprobes Inc., Stony Brook, NY, USA).

\subsection{Immunoblots}

Hippocampi were homogenised in Tris buffer (TB; $50 \mathrm{mM}$ Tris-HCl, pH 7.4), containing protease inhibitor cocktail (Thermo Fisher Scientific, Waltham, MS, USA), with a motorised pestle (Sigma-Aldrich, St. Louis, MO, USA). The homogenised tissue was initially centrifuged $10 \mathrm{~min}$ at $1000 \times \mathrm{g}$ at $4{ }^{\circ} \mathrm{C}$ and the supernatant was further centrifuged $30 \mathrm{~min}$ at $12,000 \times g$ (Centrifuge 5415R, Eppendorf, Hamburg, Germany) at $4{ }^{\circ} \mathrm{C}$. The resulting pellet, containing the membrane extracts, was resuspended in the TB. The protein content of each membrane extract was determined by the BCA protein assay kit (Thermo Fisher Scientific, Waltham, MS, USA). Forty micrograms of membrane protein were loaded onto sodium dodecyl sulphate polyacrylamide (7.5\%) gels (SDS/PAGE) in sample buffer (0.05 M Tris pH 6.8, 2\% ( $w / v)$ SDS, $10 \%(v / v)$ glycerol, $0.05 \%(v / v) \beta$-mercaptoethanol and $0.001 \%(w / v)$ bromophenol blue). The proteins were transferred to Nitrocellulose membranes using the iBlot ${ }^{\mathrm{TM}}$ Dry Blotting System (Invitrogen, Madrid, Spain), followed by immunolabelling with anti-mGlu ${ }_{5}(1: 500)$, anti- $\mathrm{G}_{\mathrm{q} / 11}$ (1:500), anti-PLC $\beta_{1}(1: 500)$ and anti- $\beta$-tubulin (1:2000) antibodies. Protein bands were visualized after application of a rabbit IgG kappa binding protein coupled to horseradish peroxidase (1:2000) using the enhanced chemiluminescence (ECL) blotting detection kit (GE Healthcare, Madrid, Spain) in a G:Box gel documentation system (Syngene, Cambridge, UK), and specific bands were quantified by densitometry using GeneTools software (Syngene). A series of primary and secondary antibody dilutions and incubation times were used to optimize the experimental conditions for the linear sensitivity range, confirming that our labelling was well below saturation levels.

\subsection{Histoblotting}

The regional distribution of $\mathrm{mGlu}_{5}$ was analysed in rodent brains, using the histoblot technique [69]. Briefly, horizontal cryostat sections $(10 \mu \mathrm{m})$ from mouse brain were overlapped with nitrocellulose membranes moistened with $48 \mathrm{mM}$ Tris-base, $39 \mathrm{mM}$ glycine, $2 \%$ $(w / v)$ sodium dodecyl sulphate and $20 \%(v / v)$ methanol for $15 \mathrm{~min}$ at room temperature $\left(\sim 20^{\circ} \mathrm{C}\right)$. After blocking in $5 \%(w / v)$ non-fat dry milk in phosphate-buffered saline for $1 \mathrm{~h}$, nitrocellulose membranes were treated with DNase I $(5 \mathrm{U} / \mathrm{mL})$, washed and incubated in $2 \%(w / v)$ sodium dodecyl sulphate and $100 \mathrm{mM} \beta$-mercaptoethanol in $100 \mathrm{mM}$ Tris- $\mathrm{HCl}$ ( $\mathrm{pH} 7.0$ ) for $60 \mathrm{~min}$ at $45^{\circ} \mathrm{C}$ to remove adhering tissue residues. After extensive washing, 
the blots were reacted with affinity-purified anti-mGlu $\mathrm{m}_{5}$ antibodies $(0.5 \mathrm{mg} / \mathrm{mL})$ in blocking solution overnight at $4{ }^{\circ} \mathrm{C}$. The bound primary antibodies were detected with alkaline phosphatase-conjugated anti-rabbit IgG secondary antibodies [69]. A series of primary and secondary antibody dilutions and incubation times were used to optimize the experimental conditions for the linear sensitivity range of the alkaline phosphatase reactions. To compare

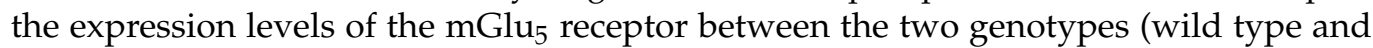
APP/PS1) and ages (1, 6 and 12-months), all nitrocellulose membranes were processed in parallel, and the same incubation time for each reagent was used for the antibody. Digital images were acquired by scanning the nitrocellulose membranes using a desktop scanner (HP Scanjet 8300). Image analysis and processing were performed using the Adobe Photoshop software (Adobe Systems, San Jose, CA, USA) as described previously [62].

\subsection{Immunohistochemistry for Electron Microscopy}

Immunohistochemical reactions at the electron microscopic level were carried out using the pre-embedding immunogold and the SDS-FRL methods, as described earlier [21,27].

Pre-embedding immunogold method. Briefly, free-floating sections obtained from the two genotypes (WT and APP/PS1) and three ages (1, 6 and 12-months) were incubated in parallel in $10 \%(v / v)$ NGS diluted in Tris buffered saline (TBS; $50 \mathrm{mM}$ Tris- $\mathrm{HCl}, 0.9 \% \mathrm{NaCl}$, $\mathrm{pH}$ 7.4). Sections were then incubated in anti-mGlu $\mathrm{m}_{5}$ antibodies $(3-5 \mu \mathrm{g} / \mathrm{mL}$ diluted in TBS containing $1 \%(v / v)$ NGS), followed by incubation in goat anti-rabbit IgG or goat antiguinea pig IgG coupled to $1.4 \mathrm{~nm}$ gold (Nanoprobes Inc., Stony Brook, NY, USA). Sections were post-fixed in $1 \%(v / v)$ glutaraldehyde and washed in double-distilled water, followed by silver enhancement of the gold particles with an HQ Silver kit (Nanoprobes Inc.). Sections were then treated with osmium tetraoxide ( $1 \%$ in $0.1 \mathrm{M}$ phosphate buffer), blockstained with uranyl acetate, dehydrated in graded series of ethanol and flat-embedded on glass slides in Durcupan (Sigma-Aldrich, St. Louis, MO, USA) resin. Regions of interest were cut at 70-90 $\mathrm{nm}$ on an ultramicrotome (Reichert Ultracut E, Leica, Vienna, Austria) and collected on single slot pioloform-coated copper grids. Ultrastructural analyses were performed in a JEOL-1010 electron microscope (JEOL Ltd., Tokyo, Japan).

SDS-FRL technique. Animals were anesthetised with sodium pentobarbital $(50 \mathrm{mg} / \mathrm{kg}$, i.p.) and perfused transcardially with saline for $1 \mathrm{~min}$, followed by perfusion with $2 \%$ paraformaldehyde in $0.1 \mathrm{M}$ phosphate buffer (PB) for $12 \mathrm{~min}$. The hippocampi were dissected and cut into sagittal slices $(130 \mu \mathrm{m})$ using a microslicer (Dosaka, Kyoto, Japan) in $0.1 \mathrm{M}$ PB. Hippocampal sections containing the CA region were then immersed in graded glycerol of $10-30 \%$ in $0.1 \mathrm{M} \mathrm{PB}$ at $4{ }^{\circ} \mathrm{C}$ overnight. Slices were frozen using a high-pressure freezing machine (HPM010, BAL-TEC, Balzers). Slices were then fractured into two parts at $-120^{\circ} \mathrm{C}$ and replicated by carbon deposition ( $5 \mathrm{~nm}$ thick), platinum $\left(60^{\circ}\right.$ unidirectional from horizontal level, $2 \mathrm{~nm}$ ), and carbon $(15 \mathrm{~nm})$ in a freeze-fracture replica machine (BAF060, BAL-TEC, Balzers). Replicas were transferred to 2.5\% SDS and 20\% sucrose in $15 \mathrm{mM}$ Tris buffer ( $\mathrm{pH} \mathrm{8.3)}$ for $18 \mathrm{~h}$ at $80{ }^{\circ} \mathrm{C}$ with shaking to dissolve tissue debris. The replicas were washed three times in TBS containing $0.05 \%$ bovine serum albumin (BSA), and then blocked with $5 \%$ BSA in the washing buffer for $1 \mathrm{~h}$ at room temperature. Next, the replicas were washed and reacted with a polyclonal rabbit antibody for $\mathrm{mGlu}_{5}(5 \mu \mathrm{g} / \mathrm{mL})$ at $15{ }^{\circ} \mathrm{C}$ overnight. Following three washes in $0.05 \%$ BSA in TBS and blocking in $5 \%$ BSA/TBS, replicas were incubated in secondary antibodies conjugated with $10 \mathrm{~nm}$ gold particles overnight at room temperature. After immunogold labelling, the replicas were immediately rinsed three times with $0.05 \%$ BSA in TBS, washed twice with distilled water, and picked up onto grids coated with pioloform (Agar Scientific, Stansted, Essex, UK).

\subsection{Quantification and Analysis of SDS-FRL Data}

The labelled replicas were examined using a transmission electron microscope (JEOL1010) and images captured at magnifications of 80,000 , and 100,000. The antibody used in this study was visualised by immunoparticles on the protoplasmic face (P-face), consistent with the intracellular location of the epitope. Non-specific background labelling 
for mGlu 5 was estimated by counting immunogold particles on the exoplasmic face (Eface) surfaces in wild type mice. Digitized images were then modified for brightness and contrast using Adobe PhotoShop CS5 (Mountain View, CA, USA) to optimize them for quantitative analysis.

Density gradient of $m \mathrm{Glu}_{5}$ along the neuronal surface. The procedure was similar to that which was used previously [62]. Briefly, immunogold labelling for mGlu 5 was achieved from replicas containing all layers of the CA1 region and DG, so that the laminar distribution could be compared under identical conditions for each animal and experimental group. Quantitative analysis of immunogold labelling for mGlu $_{5}$ was performed on 7 different dendritic compartments of pyramidal cells in all dendritic layers of the CA1 region, the somata of pyramidal cells in the stratum pyramidale, as well as on 2 dendritic compartments of granule cells in the molecular layer and granule cell layer of the DG. The dendritic compartments analysed in principal cells were the main dendritic shaft (apical dendrites), spiny branchlets (oblique dendrites) and dendritic spines. Oblique dendrites were identified based on their small diameter and the presence of at least one emerging spine from the dendritic shaft. Dendritic spines were considered as such if: (i) they emerged from a dendritic shaft, or (ii) they opposed an axon terminal. Axon terminals were identified based on: (i) the presence of an active zone (AZ) facing a postsynaptic density (PSD) recognised by an accumulation of intramembrane particles (IMPs) on the opposing exoplasmic-face (E-face) of a spine or dendrite; or (ii) the presence of synaptic vesicles on their cross-fractured portions. Non-specific background labelling was measured on E-face structures surrounding the measured P-faces. Images of the identified compartments were selected randomly over the entire dendritic tree of CA1 pyramidal cells and DG granule cells, and then captured with an ORIUS SC1000 CCD camera (Gatan, Munich, Germany). The area of the selected profiles and the number of immunoparticles were measured using our GPDQ software [27]. Immunoparticle densities were presented as mean \pm SEM between animals. Statistical comparisons were performed with GraphPad Prism 5 software (La Jolla, CA, USA).

Given that neuronal loss is observed adjacent to plaques in APP/PS1 mice [35], our quantitative analysis was performed in $A \beta$ plaque-free regions of the hippocampus to avoid the destroyed tissue in dystrophic neurites adjacent to $A \beta$ plaques. Thus, the density values expressed as immunoparticles $/ \mu \mathrm{m}^{2}$ in the APP/PS1 mice represent genuine reductions in $\mathrm{mGlu}_{5}$ receptors in different compartments of CA1 pyramidal cells and DG granule cells, regardless of any possible neuronal and/or synaptic loss.

\subsection{Controls}

To test method specificity in the procedures for electron microscopy, the primary antibody was either omitted or replaced with $5 \%(v / v)$ normal serum of the species of the primary antibody, resulting in total loss of the signal. For the pre-embedding technique, labelling patterns were also compared with those obtained by calbindin (polyclonal rabbit anti-calbindin D-9k CB9; Swant, Marly, Switzerland); only the antibodies against mGlu 5 consistently labelled excitatory synapses.

\subsection{Data Analysis}

To avoid observer bias, we performed blinded experiments for immunoblots and immohistochemistry prior to data analysis. Statistical analyses were performed using GraphPad Prism (San Diego, CA, USA) and data were presented as mean \pm SEM unless indicated otherwise. Statistical significance was defined as $p<0.05$. The statistical evaluation of the immunoblots was performed using the Student-Fisher $t$-test, with Levene's test for homogeneity of variance and the Shapiro-Wilk normality test. The application of Levene's test indicated that variances are equal, and the application of the Shapiro-Wilk test indicated that distributions were normal. To compute SEM error bars, five blots were measured from each animal. The statistical evaluation of the immunogold densities in the mouse model was performed using the two-way ANOVA test and Bonferroni post 
hoc test. Finally, statistical evaluation of the frequency of immunogold measured with pre-embedding were performed using the Student- $t$ test with Holm-Sidak correction.

Supplementary Materials: The following are available online at https:/ /www.mdpi.com/article/10 $.3390 /$ ijms22115867/s1.

Author Contributions: All authors had full access to all data in the study and take responsibility for the integrity of the data and the accuracy of the data analysis. R.L. and Y.F. designed the project; A.M.-B., R.L. and Y.F. performed SDS-FRL immunoelectron microscopy; J.L.A. and M.M. performed immunoblotting; A.M.-B., C.A. and A.E.M.-M. performed histoblot analysis; A.M.-B., R.A.-R. and A.E.M.-M. performed pre-embedding immunoelectron microscopy and its quantitative analysis; A.M.-B., R.A.-R., C.A. and R.L. analysed data; R.L. wrote the paper. All authors have read and agreed to the published version of the manuscript.

Funding: This project/research has received funding from the European Union's Horizon 2020 Framework Programme for Research and Innovation under the Specific Grant Agreement No. 785907 (Human Brain Project SGA2) to R.L. This work was supported by grants from the Spanish Ministerio de Economía y Competitividad (RTI2018-095812-B-I00) to R.L., Ministerio de Ciencia e Innovación (grant PID2019-109206GB-I00) to M.M., and Junta de Comunidades de Castilla-La Mancha (SBPLY /17/180501/000229 to RL, SBPLY/19/180501/000251 to M.M.), by UCLM (grant 2020-GRIN29108 cofinanced with the European Union FEDER) to M.M., and the Life Science Innovation Center (Research and Education Program for Life Science) at the University of Fukui and JSPS KAKENHI, Grant Numbers 19K22469 and 20H05058, to Y.F.

Institutional Review Board Statement: All animal experimental procedures were performed in accordance with Spanish (RD 1201/2015) and European Union regulations (86/609/EC), and the protocols were approved by the local Animal Care and Use Committee.

Informed Consent Statement: All co-authors of the present manuscript can certify that it has not been submitted to more than one journal for simultaneous consideration and that the manuscript has not been published previously (partly or in full). The authors also can certify that our main study is not split up into several parts to increase the quantity of submissions, that none of the data presented here have been fabricated or manipulated and that we present our own data/text/theories/ideas. All authors and authorities have explicitly provided their consent to submit the present manuscript and, in general, we all agree with the ethical responsibilities expected of authors of journal articles. Finally, all authors give consent for publication in IJMS.

Data Availability Statement: All data used and/or analysed during the current study are available from the corresponding author on reasonable request.

Acknowledgments: We thank Diane Latawiec for the English revision of the manuscript. We thank Takako Maegawa and Hitoshi Takagi of the Life Science Innovation Center at the University of Fukui for their technical assistance. Funding sources were the European Union's Horizon 2020 Framework Programme for Research and Innovation, the Spanish Ministerio de Economía y Competitividad, Ministerio de Ciencia e Innovación, Junta de Comunidades de Castilla-La Mancha (Spain) and the Life Science Innovation Center at the University of Fukui.

Conflicts of Interest: The authors of this manuscript declare that they have no competing interests.

\section{References}

1. Hyman, B.T.; Damasio, H.; Damasio, A.R.; Van Hoesen, G.W. Alzheimer's disease. Annu. Rev. Public Health 1989, 10, 115-140. [CrossRef] [PubMed]

2. Scheltens, P.; Blennow, K.; Breteler, M.M.B.; de Strooper, B.; Frisoni, G.B.; Salloway, S.; Van der Flier, W.M. Alzheimer's disease. Lancet 2016, 388, 505-517. [CrossRef]

3. Spires-Jones, T.L.; Hyman, B.T. The Intersection of Amyloid Beta and Tau at Synapses in Alzheimer's Disease. Neuron 2014, 82, 756-771. [CrossRef] [PubMed]

4. LaFerla, F.M.; Oddo, S. Alzheimer's disease: A $\beta$, tau and synaptic dysfunction. Trends Mol. Med. 2005, 11, 170-176. [CrossRef] [PubMed]

5. Llorens-Martín, M.; Blazquez-Llorca, L.; Benavides-Piccione, R.; Rabano, A.; Hernandez, F.; Avila, J.; DeFelipe, J. Selective alterations of neurons and circuits related to early memory loss in Alzheimer's disease. Front. Neuroanat. 2014, 8, 1-12. [CrossRef]

6. Ondrejcak, T.; Klyubin, I.; Hu, N.-W.; Barry, A.E.; Cullen, W.K.; Rowan, M.J. Alzheimer's Disease Amyloid $\beta$-Protein and Synaptic Function. NeuroMol. Med. 2010, 12, 13-26. [CrossRef] [PubMed] 
7. Paula-Lima, A.C.; Brito-Moreira, J.; Ferreira, S.T. Deregulation of excitatory neurotransmission underlying synapse failure in Alzheimer's disease. J. Neurochem. 2013, 126, 191-202. [CrossRef]

8. Revett, T.; Baker, G.; Jhamandas, J.; Kar, S. Glutamate system, amyloid $\beta$ peptides and tau protein: Functional interrelationships and relevance to Alzheimer disease pathology. J. Psychiatry Neurosci. 2013, 38, 6-23. [CrossRef]

9. Forner, S.; Baglietto-Vargas, D.; Martini, A.C.; Trujillo-Estrada, L.; LaFerla, F.M. Synaptic Impairment in Alzheimer's Disease: A Dysregulated Symphony. Trends Neurosci. 2017, 40, 347-357. [CrossRef]

10. Ottersen, O.P.; Storm-Mathisen, J.; Bramham, C.; Torp, R.; Laake, J.; Gundersen, V. A quantitative electron microscopic immunocytochemical study of the distribution and synaptic handling of glutamate in rat hippocampus. Prog. Brain Res. 1990, 83, 99-114. [CrossRef]

11. Lehre, K.P.; Levy, L.M.; Ottersen, O.P.; Storm-Mathisen, J.; Danbolt, N.C. Differential expression of two glial glutamate transporters in the rat brain: Quantitative and immunocytochemical observations. J. Neurosci. 1995, 15, 1835-1853. [CrossRef]

12. Hollmann, M.; Heinemann, S. Cloned Glutamate Receptors. Annu. Rev. Neurosci. 1994, 17, 31-108. [CrossRef]

13. Nakanishi, S. Metabotropic glutamate receptors: Synaptic transmission, modulation, and plasticity. Neuron 1994, 13, $1031-1037$. [CrossRef]

14. Pin, J.P.; Duvoisin, R. The metabotropic glutamate receptors: Structure and functions. Neuropharmacology 1995, 34, 1-26. [CrossRef]

15. Nicoletti, F.; Bockaert, J.; Collingridge, G.L.; Conn, P.J.; Ferraguti, F.; Schoepp, D.D.; Wroblewski, J.T.; Pin, J.P. Metabotropic glutamate receptors: From the workbench to the bedside. Neuropharmacology 2011, 60, 1017-1041. [CrossRef]

16. Anwyl, R. Metabotropic glutamate receptors: Electrophysiological properties and role in plasticity. Brain Res. Rev. 1999, 29, 83-120. [CrossRef]

17. Lu, Y.M.; Jia, Z.; Janus, C.; Henderson, J.T.; Gerlai, R.; Wojtowicz, J.M.; Roder, J.C. Mice lacking metabotropic glutamate receptor 5 show impaired learning and reduced CA1 long-term potentiation (LTP) but normal CA3 LTP. J. Neurosci. 1997, 17, 5196-5205. [CrossRef]

18. Ayala, J.E.; Chen, Y.; Banko, J.L.; Sheffler, D.J.; Williams, R.; Telk, A.N.; Watson, N.L.; Xiang, Z.; Zhang, Y.; Jones, P.J.; et al. MGluR5 Positive Allosteric Modulators Facilitate both Hippocampal LTP and LTD and Enhance Spatial Learning. Neuropsychopharmacology 2009, 34, 2057-2071. [CrossRef]

19. Abe, T.; Sugihara, H.; Nawa, H.; Shigemoto, R.; Mizuno, N.; Nakanishi, S. Molecular characterization of a novel metabotropic glutamate receptor mGluR5 coupled to inositol phosphate/Ca2+ signal transduction. J. Biol. Chem. 1992, 267, 13361-13368. [CrossRef]

20. Shigemoto, R.; Nomura, S.; Ohishi, H.; Sugihara, H.; Nakanishi, S.; Mizuno, N. Immunohistochemical localization of a metabotropic glutamate receptor, mGluR5, in the rat brain. Neurosci. Lett. 1993, 163, 53-57. [CrossRef]

21. Luján, R.; Nusser, Z.; Roberts, J.D.B.; Shigemoto, R.; Somogyi, P. Perisynaptic location of metabotropic glutamate receptors mGluR1 and mGluR5 on dendrites and dendritic spines in the rat hippocampus. Eur. J. Neurosci. 1996, 8, 1488-1500. [CrossRef]

22. Luján, R.; Roberts, J.D.B.; Shigemoto, R.; Ohishi, H.; Somogyi, P. Differential plasma membrane distribution of metabotropic glutamate receptors $m G l u R 1 \alpha$, GGluR2 and mGluR5, relative to neurotransmitter release sites. J. Chem. Neuroanat. 1997, 13, 219-241. [CrossRef]

23. Harney, S.C.; Rowan, M.; Anwyl, R. Long-term depression of NMDA receptor-mediated synaptic transmission is dependent on activation of metabotropic glutamate receptors and is altered to long-term potentiation by low intracellular calcium buffering. $J$. Neurosci. 2006, 26, 1128-1132. [CrossRef]

24. Kumar, A.; Dhull, D.K.; Mishra, P.S. Therapeutic potential of mGluR5 targeting in Alzheimer's disease. Front. Neurosci. 2015, 9. [CrossRef]

25. Renner, M.; Lacor, P.N.; Velasco, P.T.; Xu, J.; Contractor, A.; Klein, W.L.; Triller, A. Deleterious Effects of Amyloid $\beta$ Oligomers Acting as an Extracellular Scaffold for mGluR5. Neuron 2010, 66, 739-754. [CrossRef]

26. Um, J.W.; Kaufman, A.C.; Kostylev, M.; Heiss, J.K.; Stagi, M.; Takahashi, H.; Kerrisk, M.E.; Vortmeyer, A.; Wisniewski, T.; Koleske, A.J.; et al. Metabotropic Glutamate Receptor 5 Is a Coreceptor for Alzheimer A $\beta$ Oligomer Bound to Cellular Prion Protein. Neuron 2013, 79, 887-902. [CrossRef]

27. Luján, R.; Aguado, C.; Ciruela, F.; Cózar, J.; Kleindienst, D.; de la Ossa, L.; Bettler, B.; Wickman, K.; Watanabe, M.; Shigemoto, R.; et al. Differential association of GABA B receptors with their effector ion channels in Purkinje cells. Brain Struct. Funct. 2018, 223, 1565-1587. [CrossRef]

28. Thathiah, A.; De Strooper, B. The role of G protein-coupled receptors in the pathology of Alzheimer's disease. Nat. Rev. Neurosci. 2011, 12, 73-87. [CrossRef]

29. Cartmell, J.; Schoepp, D.D. Regulation of Neurotransmitter Release by Metabotropic Glutamate Receptors. J. Neurochem. 2002, 75, 889-907. [CrossRef]

30. Neyman, S.; Manahan-Vaughan, D. Metabotropic glutamate receptor 1 (mGluR1) and 5 (mGluR5) regulate late phases of LTP and LTD in the hippocampal CA1 region in vitro. Eur. J. Neurosci. 2008, 27, 1345-1352. [CrossRef]

31. Dinamarca, M.C.; Ríos, J.A.; Inestrosa, N.C. Postsynaptic receptors for amyloid- $\beta$ oligomers as mediators of neuronal damage in Alzheimer's disease. Front. Physiol. 2012. [CrossRef] [PubMed]

32. Caraci, F.; Nicoletti, F.; Copani, A. Metabotropic glutamate receptors: The potential for therapeutic applications in Alzheimer's disease. Curr. Opin. Pharmacol. 2018, 38, 1-7. [CrossRef] [PubMed] 
33. Ribeiro, F.M.; Paquet, M.; Cregan, P.S.; Ferguson, S.G.S. Group I Metabotropic Glutamate Receptor Signalling and its Implication in Neurological Disease. CNS Neurol. Disord. Drug Targets 2010, 9, 574-595. [CrossRef] [PubMed]

34. Merino-Serrais, P.; Knafo, S.; Alonso-Nanclares, L.; Fernaud-Espinosa, I.; Defelipe, J. Layer-specific alterations to CA1 dendritic spines in a mouse model of Alzheimer's disease. Hippocampus 2011, 21, 1037-1044. [CrossRef]

35. Alonso-Nanclares, L.; Merino-Serrais, P.; Gonzalez, S.; Defelipe, J. Synaptic changes in the dentate gyrus of APP/PS1 transgenic mice revealed by electron microscopy. J. Neuropathol. Exp. Neurol. 2013, 72, 386-395. [CrossRef]

36. Šišková, Z.; Justus, D.; Kaneko, H.; Friedrichs, D.; Henneberg, N.; Beutel, T.; Pitsch, J.; Schoch, S.; Becker, A.; vonderKammer, H.; et al. Dendritic structural degeneration is functionally linked to cellular hyperexcitability in a mouse model of alzheimer's disease. Neuron 2014, 84, 1023-1033. [CrossRef]

37. Martín-Belmonte, A.; Aguado, C.; Alfaro-Ruíz, R.; Itakura, M.; Moreno-Martínez, A.E.; de la Ossa, L.; Molnár, E.; Fukazawa, Y.; Luján, R. Age-Dependent Shift of AMPA Receptors from Synapses to Intracellular Compartments in Alzheimer's Disease: Immunocytochemical Analysis of the CA1 Hippocampal Region in APP/PS1 Transgenic Mouse Model. Front. Aging Neurosci. 2020, 12. [CrossRef]

38. Haas, L.T.; Salazar, S.V.; Kostylev, M.A.; Um, J.W.; Kaufman, A.C.; Strittmatter, S.M. Metabotropic glutamate receptor 5 couples cellular prion protein to intracellular signalling in Alzheimer's disease. Brain 2016, 139, 526-546. [CrossRef]

39. Raka, F.; Di Sebastiano, A.R.; Kulhawy, S.C.; Ribeiro, F.M.; Godin, C.M.; Caetano, F.A.; Angers, S.; Ferguson, S.S.G. $\mathrm{Ca} 2+/$ Calmodulin-dependent protein Kinase II interacts with group i Metabotropic Glutamate and facilitates Receptor Endocytosis and ERK1/2 signaling: Role of $\beta$-Amyloid. Mol. Brain 2015, 8. [CrossRef]

40. Um, J.W.; Nygaard, H.B.; Heiss, J.K.; Kostylev, M.A.; Stagi, M.; Vortmeyer, A.; Wisniewski, T.; Gunther, E.C.; Strittmatter, S.M. Alzheimer amyloid- $\beta$ oligomer bound to postsynaptic prion protein activates Fyn to impair neurons. Nat. Neurosci. 2012, 15, 1227-1235. [CrossRef]

41. Findley, C.A.; Bartke, A.; Hascup, K.N.; Hascup, E.R. Amyloid Beta-Related Alterations to Glutamate Signaling Dynamics During Alzheimer's Disease Progression. ASN Neuro 2019, 11. [CrossRef]

42. Hamilton, A.; Esseltine, J.L.; Devries, R.A.; Cregan, S.P.; Ferguson, S.S.G. Metabotropic glutamate receptor 5 knockout reduces cognitive impairment and pathogenesis in a mouse model of Alzheimer's disease. Mol. Brain 2014, 7. [CrossRef]

43. Abd-Elrahman, K.S.; Albaker, A.; de Souza, J.M.; Ribeiro, F.M.; Schlossmacher, M.G.; Tiberi, M.; Hamilton, A.; Ferguson, S.S.G. $\mathrm{A} \beta$ oligomers induce pathophysiological mGluR5 signaling in Alzheimer's disease model mice in a sex-selective manner. Sci. Signal. 2020, 13. [CrossRef]

44. Albasanz, J.L.; Dalfó, E.; Ferrer, I.; Martín, M. Impaired metabotropic glutamate receptor/phospholipase C signaling pathway in the cerebral cortex in Alzheimer's disease and dementia with Lewy bodies correlates with stage of Alzheimer's-disease-related changes. Neurobiol. Dis. 2005, 20, 685-693. [CrossRef]

45. Simonyi, A.; Ngomba, R.T.; Storto, M.; Catania, M.V.; Miller, L.A.; Youngs, B.; DiGorgi-Gerevini, V.; Nicoletti, F.; Sun, G.Y. Expression of groups I and II metabotropic glutamate receptors in the rat brain during aging. Brain Res. 2005, 1043, 95-106. [CrossRef]

46. Sánchez-Melgar, A.; Albasanz, J.L.; Pallàs, M.; Martín, M. Resveratrol Differently Modulates Group i Metabotropic Glutamate Receptors Depending on Age in SAMP8 Mice. ACS Chem. Neurosci. 2020, 11, 1770-1780. [CrossRef]

47. Lee, M.; Lee, H.J.; Park, I.S.; Park, J.A.; Kwon, Y.J.; Ryu, Y.H.; Kim, C.H.; Kang, J.H.; Hyun, I.Y.; Lee, K.C.; et al. A $\beta$ pathology downregulates brain mGluR5 density in a mouse model of Alzheimer. Neuropharmacology 2018, 133, 512-517. [CrossRef] [PubMed]

48. Lee, M.; Lee, H.J.; Jeong, Y.J.; Oh, S.J.; Kang, K.J.; Han, S.J.; Nam, K.R.; Lee, Y.J.; Lee, K.C.; Ryu, Y.H.; et al. Age dependency of mGluR5 availability in 5xFAD mice measured by PET. Neurobiol. Aging 2019, 84, 208-216. [CrossRef] [PubMed]

49. Masugi-Tokita, M.; Shigemoto, R. High-resolution quantitative visualization of glutamate and GABA receptors at central synapses. Curr. Opin. Neurobiol. 2007, 17, 387-393. [CrossRef] [PubMed]

50. Tanaka, J.I.; Matsuzaki, M.; Tarusawa, E.; Momiyama, A.; Molnar, E.; Kasai, H.; Shigemoto, R. Number and density of AMPA receptors in single synapses in immature cerebellum. J. Neurosci. 2005, 25, 799-807. [CrossRef]

51. Romano, C.; Sesma, M.A.; McDonald, C.T.; O'malley, K.; van den Pol, A.N.; Olney, J.W. Distribution of metabotropic glutamate receptor mGluR5 immunoreactivity in rat brain. J. Comp. Neurol. 1995, 355, 455-469. [CrossRef]

52. Shigemoto, R.; Nakanishi, S.; Mizuno, N. Distribution of the mRNA for a metabotropic glutamate receptor (mGluR1) in the central nervous system: An in situ hybridization study in adult and developing rat. J. Comp. Neurol. 1992, 322, 121-135. [CrossRef]

53. Berthele, A.; Laurie, D.J.; Platzer, S.; Zieglgänsberger, W.; Tölle, T.R.; Sommer, B. Differential expression of rat and human type 1 metabotropic glutamate receptor splice variant messenger RNAs. Neuroscience 1998, 85, 733-749. [CrossRef]

54. Poncer, J.C.; Shinozaki, H.; Miles, R. Dual modulation of synaptic inhibition by distinct metabotropic glutamate receptors in the rat hippocampus. J. Physiol. 1995, 485, 121-134. [CrossRef]

55. Popkirov, S.G.; Manahan-Vaughan, D. Involvement of the metabotropic glutamate receptor mGluR5 in NMDA receptordependent, learning-facilitated long-term depression in CA1 synapses. Cereb. Cortex 2011, 21, 501-509. [CrossRef]

56. García-Negredo, G.; Soto, D.; Llorente, J.; Morató, X.; Galenkamp, K.M.O.; Gómez-Soler, M.; Fernández-Dueñas, V.; Watanabe, M.; Adelman, J.P.; Shigemoto, R.; et al. Coassembly and coupling of SK2 channels and mGlu5 receptors. J. Neurosci. 2014, 34, 14793-14802. [CrossRef] 
57. El-Hassar, L.; Hagenston, A.M.; D’Angelo, L.B.; Yeckel, M.F. Metabotropic glutamate receptors regulate hippocampal CA1 pyramidal neuron excitability via Ca 2+ wave-dependent activation of SK and TRPC channels. J. Physiol. 2011, 589, 3211-3229. [CrossRef]

58. Kato, H.K.; Kassai, H.; Watabe, A.M.; Aiba, A.; Manabe, T. Functional coupling of the metabotropic glutamate receptor, InsP3 receptor and L-type Ca2+ channel in mouse CA1 pyramidal cells. J. Physiol. 2012, 590, 3019-3034. [CrossRef]

59. Reiner, A.; Levitz, J. Glutamatergic Signaling in the Central Nervous System: Ionotropic and Metabotropic Receptors in Concert. Neuron 2018, 98, 1080-1098. [CrossRef]

60. Jankowsky, J.L.; Fadale, D.J.; Anderson, J.; Xu, G.M.; Gonzales, V.; Jenkins, N.A.; Copeland, N.G.; Lee, M.K.; Younkin, L.H.; Wagner, S.L.; et al. Mutant presenilins specifically elevate the levels of the 42 residue $\beta$-amyloid peptide in vivo: Evidence for augmentation of a 42-specific $\gamma$ secretase. Hum. Mol. Genet. 2004, 13, 159-170. [CrossRef]

61. Martín-Belmonte, A.; Aguado, C.; Alfaro-Ruíz, R.; Moreno-Martínez, A.E.; de la Ossa, L.; Martínez-Hernández, J.; Buisson, A.; Shigemoto, R.; Fukazawa, Y.; Luján, R. Density of GABAB Receptors Is Reduced in Granule Cells of the Hippocampus in a Mouse Model of Alzheimer's Disease. Int. J. Mol. Sci. 2020, 21, 2459. [CrossRef]

62. Martín-Belmonte, A.; Aguado, C.; Alfaro-Ruíz, R.; Moreno-Martínez, A.E.; de la Ossa, L.; Martínez-Hernández, J.; Buisson, A.; Früh, S.; Bettler, B.; Shigemoto, R.; et al. Reduction in the neuronal surface of post and presynaptic GABAB receptors in the hippocampus in a mouse model of Alzheimer's disease. Brain Pathol. 2020, 30, 554-575. [CrossRef]

63. Lin, M.T.; Luján, R.; Watanabe, M.; Adelman, J.P.; Maylie, J. SK2 channel plasticity contributes to LTP at Schaffer collateral-CA1 synapses. Nat. Neurosci. 2008, 11, 170-177. [CrossRef]

64. Aniksztejn, L.; Otani, S.; Ben-Ari, Y. Quisqualate Metabotropic Receptors Modulate NMDA Currents and Facilitate Induction of Long-Term Potentiation Through Protein Kinase C. Eur. J. Neurosci. 1992, 4, 500-505. [CrossRef]

65. Conquet, F.; Bashir, Z.I.; Davies, C.H.; Daniel, H.; Ferraguti, F.; Bordi, F.; Franz-Bacon, K.; Reggiani, A.; Matarese, V.; Condé, F.; et al. Motor deficit and impairment of synaptic plasticity in mice lacking mGluR1. Nature 1994, 372, 237-243. [CrossRef]

66. Jankowsky, J.L.; Slunt, H.H.; Ratovitski, T.; Jenkins, N.A.; Copeland, N.G.; Borchelt, D.R. Co-expression of multiple transgenes in mouse CNS: A comparison of strategies. Biomol. Eng. 2001, 17, 157-165. [CrossRef]

67. Tanaka, J.; Nakagawa, S.; Kushiya, E.; Yamasaki, M.; Fukaya, M.; Iwanaga, T.; Simon, M.I.; Sakimura, K.; Kano, M.; Watanabe, M. Gq protein $\alpha$ subunits $\mathrm{G} \alpha q$ and $\mathrm{G} \alpha 11$ are localized at postsynaptic extra-junctional membrane of cerebellar Purkinje cells and hippocampal pyramidal cells. Eur. J. Neurosci. 2000, 12, 781-792. [CrossRef]

68. Uchigashima, M.; Narushima, M.; Fukaya, M.; Katona, I.; Kano, M.; Watanabe, M. Subcellular arrangement of molecules for 2-arachidonoyl-glycerol-mediated retrograde signaling and its physiological contribution to synaptic modulation in the striatum. J. Neurosci. 2007, 27, 3663-3676. [CrossRef] [PubMed]

69. Aguado, C.; Luján, R. The Histoblot Technique: A Reliable Approach to Analyze Expression Profile of Proteins and to Predict Their Molecular Association BT-Co-Immunoprecipitation Methods for Brain Tissue. In Neuromethods; Odagaki, Y., Borroto-Escuela, D.O., Eds.; Springer: New York, NY, USA, 2019; pp. 65-88, ISBN 978-1-4939-8985-0. 